\title{
Synthesis, Spectroscopic Characterisation, and Biopotential and DNA Cleavage Applications of Mixed Ligand 4-N,N-Dimethylaminopyridine Metal Complexes
}

\author{
C. Surendra Dilip, ${ }^{1}$ K. Manikandan, ${ }^{1}$ \\ D. Rajalaxmi (a) Subahashini, ${ }^{2}$ and R. Thiruneelakandan ${ }^{1}$ \\ ${ }^{1}$ Anna University, BIT Campus, Tiruchirappalli, Tamil Nadu 620 024, India \\ ${ }^{2}$ Saranathan College of Engineering, Panjappur, Tiruchirappalli 12, Tamil Nadu 620 012, India \\ Correspondence should be addressed to C. Surendra Dilip; cs_dilip@yahoo.co.in
}

Received 8 May 2013; Revised 23 August 2013; Accepted 29 August 2013

Academic Editor: Josefina Pons

Copyright (c) 2013 C. Surendra Dilip et al. This is an open access article distributed under the Creative Commons Attribution License, which permits unrestricted use, distribution, and reproduction in any medium, provided the original work is properly cited.

\begin{abstract}
The mixed ligand transition metal complexes of 4-N,N-dimethylaminopyridine (DP) and chloride as primary and secondary ligands with the general formula $\left[\mathrm{M}(\mathrm{DP})_{3} \mathrm{Cl}_{3}\right] ; \mathrm{M}=\mathrm{Cr}(\mathrm{III})$ and $\mathrm{Fe}(\mathrm{III}) ;\left[\mathrm{M}^{\prime}(\mathrm{DP})_{4} \mathrm{Cl}_{2}\right] \mathrm{M}^{\prime}=\mathrm{Co}(\mathrm{II}), \mathrm{Ni}(\mathrm{II}), \mathrm{Cu}(\mathrm{II})$, and $\mathrm{Cd}(\mathrm{II})$ were synthesized in a microwave oven. The complexes were characterized by FT-IR and UV, ${ }^{1} \mathrm{HNMR},{ }^{13} \mathrm{CNMR}$ spectra, TG/DTG, and various physicoanalytical techniques. From the magnetic moment measurements and the electronic spectral data, a distorted octahedral geometry was proposed for the complexes. The complexes express similar trend of thermal behaviour such that they lose water of hydration initially with the subsequent emission of organic and inorganic fragments and leave left the metal oxides as residue. The activation thermodynamic parameters, such as $E^{*}, \Delta H^{*}, \Delta S^{*}$, and $\Delta G^{*}$ of the metal complexes, illustrate the spontaneous formation of the complexes. The antimicrobial studies against various pathogenic bacterial and fungal serums insist on that the enhanced potential of the complexes over their ligand and their biopotential properties increases with concentration. The DNA interaction of the synthesized complexes on CT-DNA was investigated by UV-Vis spectroscopy, viscosity, thermal denaturation, and electroanalytical experiments and their binding constants $\left(K_{b}\right)$ were also calculated.
\end{abstract}

\section{Introduction}

The search for soluble bioactive compounds of metals that are suitable for nutritional supplementation to humans is a long standing problem and persists to provide enough thrust for the fundamental research. The aromatic heterocyclic compounds have an extensive role in many biological systems including clinical, analytical and catalysis in organic synthesis [1-3]. Metal complexes are useful for the pharmaceutical purposes because of their potential ability to bind DNA via multitude interactions and cleave the duplex by virtue of their reactivity.

Understanding of the DNA-metal complexes interactions are driven by few applications, which include therapeutic approaches, nucleic acid conformations, and nanopharmaceuticals. The characterisation of DNA recognition by redox and photoactive studies are substantially aided by studying the DNA cleavage ability of the metal complexes. Double strand breaks in duplex are noteworthy to study due to the cell lethality than single strand breaks, since the double strand breaks are less readily renovated by the DNA repair mechanisms [4-8]. It is remarkable that the complexes alone were proficient in bringing about the oxidative as well as the rare hydrolytic cleavage of DNA double strand. The present work attempts to look at this aspect on the involvement of transition metal compounds on biomolecules by the antimicrobial and DNA binding and cleavage applications with the participation of the mixed ligand complexes of 4$\mathrm{N}, \mathrm{N}$-dimethylaminopyridine and chloride ions with some biologically active metal ions. 


\section{Experimental}

2.1. Materials and Reagents. All chemicals used such as 4N,N-dimethylaminopyridine (Sigma), sodium chloride (Sigma), Cr(III), Mn(II), Fe(III), Co(II), and Ni(II) chloride hexahydrates $(\mathrm{BDH}) ; \mathrm{Cd}(\mathrm{II})$ and $\mathrm{Cu}(\mathrm{II})$ chloride dihydrate (Sigma) $\mathrm{Mn}(\mathrm{II})$ and $\mathrm{Fe}(\mathrm{III})$ nitrate (Sigma), disodium salt of ethylenediaminetetraacetic acid (EDTA) (Analar), ammonia solution $(33 \% \mathrm{v} / \mathrm{v})$, and ammonium chloride were of analytical reagent grade (AR) and of the highest purity. Spectroscopically pure $(\mathrm{BDH})$ organic solvents including dimethyl sulphoxide, methyl chloride, absolute ethyl alcohol, and dimethylformamine (DMF) were used. Hydrochloric and nitric acids (Merck) were used for metal estimation.

2.2. Instruments. Open capillaries were used to determine melting points and were uncorrected. Elemental microanalyses of the separated solid chelates for $\mathrm{C}, \mathrm{H}, \mathrm{N}$, and $\mathrm{S}$ were performed at SAIF, CUSAT, Cochin. The analyses were repeated twice to check the accuracy of the results obtained. The molar conductance of solid complexes in DMF is measured using Sybron-Barnstead conductometer (Meter-PM.6, E = 3406). Infrared spectra were recorded on a Perkin-Elmer FT-IR type 1650 spectrophotometer in the wave number region 4000$200 \mathrm{~cm}^{-1}$ using $\mathrm{KBr}$ pellets. The solid reflectance spectra were measured on a Shimadzu 3101 pc spectrophotometer. The molar magnetic susceptibility is measured on powdered samples using the Faraday method. The diamagnetic corrections were made by Pascal's constant and $\mathrm{Hg}\left[\mathrm{Co}(\mathrm{SCN})_{4}\right]$ is used as a calibrant. The ${ }^{1} \mathrm{H}$ NMR spectra were recorded using $300 \mathrm{MHz}$ Varian-Oxford Mercury for the deuterated solvent water $\left(\mathrm{D}_{2} \mathrm{O}\right)$ and the spectra were recorded extended from 0 to $15 \mathrm{ppm}$. Cyclic voltammetric measurements were carried out on a BAS CV $50 \mathrm{~W}$ electrochemical analyzing system (accuracy $\pm 1.0 \mathrm{mV}$ ). Cyclic voltammograms of all the complexes were recorded in 1:9 water-acetonitrile solutions, with a $0.1 \mathrm{M}$ tetrabutyl ammonium perchlorate (TBAP) as supporting electrolyte and glassy carbon as the working electrode. The thermal analyses (TG, DTG, and DTA) were carried out in dynamic nitrogen atmosphere $\left(20 \mathrm{~mL} \mathrm{~min}^{-1}\right)$ with a heating rate of $10^{\circ} \mathrm{C} \mathrm{min}{ }^{-1}$ using Shimadzu TG-60 H and DTA-60 $\mathrm{H}$ thermal analyzers.

2.3. Synthesis of Metal Complexes. A solution of metal nitrates (0.5 mM) [Cr(III) $0.133 \mathrm{~g} ; \mathrm{Mn}(\mathrm{II}) 0.127 \mathrm{~g} ; \mathrm{Fe}(\mathrm{III}) 0.122 \mathrm{~g}$; $\mathrm{Co}(\mathrm{II}) \quad 0.119 \mathrm{~g} ; \mathrm{Ni}(\mathrm{II}) \quad 0.119 \mathrm{~g} ; \mathrm{Cu}(\mathrm{II}) \quad 0.085 \mathrm{~g}$ and $\mathrm{Cd}(\mathrm{II})$ $0.092 \mathrm{~g}$ ] dissolved in ethanol is gradually added to a stirred ethanolic solution of 4 -N,N-dimethylaminopyridine (DP) ligand $(1.0 \mathrm{mM}, 0.122 \mathrm{~g})$, in a (metal : ligand) molar ratio of $1: 2$. Further to this reaction mixture, a solution of $1.0 \mathrm{mM}$ sodium chloride $(1.0 \mathrm{mM}, 0.058 \mathrm{~g})$ dissolved in methanol was added gradually with constant stirring. The resultant mixture was kept undisturbed and irradiated at a stable medium power level $(600 \mathrm{~W})$ in a microwave oven for about 3 minutes time period.

The precipitated solid complexes were filtered and washed several times with $50 \%(\mathrm{v} / \mathrm{v})$ ethanol-water to remove any traces of unreacted starting materials. Finally, the complexes were washed with diethyl ether and dried in vacuum desiccator over anhydrous $\mathrm{CaCl}_{2}$. The complexes synthesised by the microwave method have a good yield percentage (more than $80 \%$ for all the complexes) over the conventional methods (which have only 50-70\% yield) also arrived to have the same products [9]. The other metal: ligand molar ratios $(1: 3 ; 1: 4$, etc., $\mathrm{M}: \mathrm{L})$ also were tried but they were not given successful results.

\subsection{Determination of the Metal Content. A known weight} of each complex is digested with concentrated nitric acid and hydrochloric acid mixture $(1: 3 \mathrm{v} / \mathrm{v})$. The excess acid is fumed off and the resulting solution is evaporated to dryness. The residue is then extracted with distilled water and used for quantitative estimation of the metal ions. $\mathrm{Cu}$ (II) ion is estimated volumetrically by iodometric method, and $\mathrm{Zn}$ (II) ion is estimated volumetrically by titrating against EDTA using Eriochrome Black T as indicator. $\mathrm{Cr}$ (III), $\mathrm{Co}$ (II), Ni(II), and $\mathrm{Cd}(\mathrm{II})$ ions were estimated gravimetrically as $\mathrm{BaCrO}_{4}$, $\mathrm{Co}\left[\mathrm{Hg}(\mathrm{SCN})_{4}\right],\left[\mathrm{Ni}(\mathrm{DMG})_{2}\right]$, and $\mathrm{CdS}$, respectively [10].

\subsection{Biological Activity}

2.5.1. Antibacterial Screening. Antibacterial activity is tested against B. subtilis, S. aureus, E. coli, P. aeruginosa, and $P$. vulgaris using the paper disc plate method. Each of the compounds is dissolved in DMSO and the solutions of the concentrations $(100$ and $200 \mu \mathrm{g} / \mathrm{mL})$ were prepared separately. Paper discs of Whatman filter paper (number 42) of uniform diameter $(2 \mathrm{~cm})$ were cut and sterilized in an autoclave. The paper discs soaked in the desired concentration of the complex solutions were placed aseptically in the petri dishes containing nutrient agar media (agar $20 \mathrm{~g}+$ beef extract $3 \mathrm{~g}+$ peptone $5 \mathrm{~g}$ ) seeded with each bacterial serums separately. The petri dishes were incubated at $37^{\circ} \mathrm{C}$ and the inhibition zones were recorded after $24 \mathrm{~h}$ of incubation. The antibacterial activity of a common standard antibiotic tetracycline was also recorded using the same procedure as above at the same concentrations and solvent.

2.5.2. Antifungal Screening. The antifungal activity of the standard fungicide (Flucanazone), ligand, and complexes was tested for their effect on the growth of microbial cultures and studied for their interaction with C. Albicans, A. niger, and A. Fumigates using Czapek's agar medium having the composition glucose $20 \mathrm{~g}$, starch $20 \mathrm{~g}$, agar-agar $20 \mathrm{~g}$, and distilled water $1000 \mathrm{~mL}$. To this medium, a requisite amount of the compounds was added. The medium was then poured into petri plates and the spores of fungi were placed in the medium with the help of Inoculum's needle. These petri plates were wrapped in polythene bags containing a few drops of alcohol and were placed in an incubator at $30 \pm 2^{\circ} \mathrm{C}$. The controls were run with three replicates used in each case. The linear growth of the fungus was recorded by measuring the diameter of the fungal colony after $96 \mathrm{~h}$ and the percentage inhibition was calculated by the following equation:

$$
\% I=d C-\frac{d T}{d C} \times 100
$$


TAble 1: Physical and analytical data of the complexes.

\begin{tabular}{|c|c|c|c|c|c|c|c|c|c|c|}
\hline Complexes & Colour & Mol. wt. & $\begin{array}{l}\text { M.P. } \\
\left({ }^{\circ} \mathrm{C}\right)\end{array}$ & $\begin{array}{c}\text { Yield } \\
(\%)\end{array}$ & $\% \mathrm{M}$ & $\% \mathrm{C}$ & $\% \mathrm{H}$ & $\% \mathrm{~N}$ & $\begin{array}{l}\mu_{\text {effi. }} \\
\text { B.M. }\end{array}$ & $\begin{array}{l}\text { Molar cond. } \\
\left(\Omega^{-1} \mathrm{~cm}^{2} \mathrm{~mol}^{-1}\right)\end{array}$ \\
\hline$\left[\mathrm{CrCl}_{3}(\mathrm{DP})_{3}\right]$ & Pale brown & 524 & 280 & 85 & $\begin{array}{l}9.96 \\
(10.05)\end{array}$ & $\begin{array}{c}48.21 \\
(48.09)\end{array}$ & $\begin{array}{c}5.85 \\
(5.72)\end{array}$ & $\begin{array}{c}13.01 \\
(13.74)\end{array}$ & 3.72 & 25.24 \\
\hline$\left[\mathrm{MnCl}_{2}(\mathrm{DP})_{4}\right]$ & Mercedes red & 604 & 290 & 80 & $\begin{array}{c}9.05 \\
(9.10)\end{array}$ & $\begin{array}{c}55.50 \\
(55.62)\end{array}$ & $\begin{array}{c}6.84 \\
(6.62)\end{array}$ & $\begin{array}{c}18.10 \\
(18.54)\end{array}$ & 5.35 & 23.46 \\
\hline$\left[\mathrm{FeCl}_{3}(\mathrm{DP})_{3}\right]$ & Reddish brown & 528 & 290 & 80 & $\begin{array}{c}10.46 \\
(10.60)\end{array}$ & $\begin{array}{c}48.02 \\
(47.79)\end{array}$ & $\begin{array}{c}5.88 \\
(5.52)\end{array}$ & $\begin{array}{c}13.20 \\
(13.62)\end{array}$ & 5.61 & 27.72 \\
\hline$\left[\mathrm{CoCl}_{2}(\mathrm{DP})_{4}\right]$ & Pink & 608 & 285 & 85 & $\begin{array}{c}9.22 \\
(9.70)\end{array}$ & $\begin{array}{c}55.42 \\
(55.26)\end{array}$ & $\begin{array}{c}6.64 \\
(6.57)\end{array}$ & $\begin{array}{c}18.24 \\
(18.42)\end{array}$ & 4.54 & 21.93 \\
\hline$\left[\mathrm{NiCl}_{2}(\mathrm{DP})_{4}\right]$ & Green & 607 & 278 & 85 & $\begin{array}{c}9.26 \\
(9.70)\end{array}$ & $\begin{array}{c}55.36 \\
(55.26)\end{array}$ & $\begin{array}{c}6.68 \\
(6.57)\end{array}$ & $\begin{array}{c}18.32 \\
(18.45)\end{array}$ & 2.83 & 24.42 \\
\hline$\left[\mathrm{CuCl}_{2}(\mathrm{DP})_{4}\right]$ & olive green & 612 & 275 & 85 & $\begin{array}{c}10.22 \\
(10.29)\end{array}$ & $\begin{array}{c}54.36 \\
(54.90)\end{array}$ & $\begin{array}{c}6.86 \\
(6.53)\end{array}$ & $\begin{array}{c}18.42 \\
(18.30)\end{array}$ & 1.82 & 23.58 \\
\hline$\left[\mathrm{CdCl}_{2}(\mathrm{DP})_{4}\right]$ & Colourless & 661 & 280 & 80 & $\begin{array}{c}9.22 \\
(9.70)\end{array}$ & $\begin{array}{c}55.42 \\
(55.26)\end{array}$ & $\begin{array}{c}6.79 \\
(6.05) \\
\end{array}$ & $\begin{array}{l}16.80 \\
(16.94)\end{array}$ & - & 25.25 \\
\hline
\end{tabular}

The values of elemental analysis are found (calculated).

where $d C$ and $d T$ were the diameters of the fungus colony in the control and test plates, respectively, wherein clear or inhibition zones were detected around each hole. DMF $(0.1 \mathrm{~mL})$ alone was used as a control under the same condition for each organism and by subtracting the diameter of inhibition zone resulting with DMF from that obtained in each case; both antibacterial and antifungal activities could be calculated as a mean of the three replicates.

2.6. DNA Binding and Cleavage Experiments. The concentration of $C T$-DNA per nucleotide $[C(p)]$ was measured using its known extinction coefficient at $260 \mathrm{~nm}\left(6600 \mathrm{M}^{-1} \mathrm{~cm}^{-1}\right)$. The absorbance for CT-DNA was measured at $260 \mathrm{~nm}$ (A260) and at $280 \mathrm{~nm}$ (A280) to check its purity. The ratio A260/A280 was found to be 1.84 , indicating that $C T$ DNA was satisfactorily free from protein. A buffer $[5 \mathrm{mM}$ tris(hydroxymethyl) aminomethane, tris, $\mathrm{pH} 7.2,50 \mathrm{mM}$ $\mathrm{NaCl}$ ] was used for the absorption, viscosity, and thermal denaturation experiments.

The extent of cleavage of super coiled (SC) CT-DNA $(0.5 \mu \mathrm{L}, 0.5 \mu \mathrm{g})$ to its nicked circular (NC) form is determined by agarose gel electrophoresis in Tris- $\mathrm{HCl}$ buffer $(50 \mathrm{mM}$, $\mathrm{pH}$ 7.2) containing $\mathrm{NaCl}(50 \mathrm{mM})$. In the cleavage reactions, the $30 \mu \mathrm{M}$ and $20 \mu \mathrm{M}$ complexes in $18 \mu \mathrm{L}$ buffer were photoirradiated using monochromatic UV or visible light. The samples were then incubated for $1 \mathrm{~h}$ at $37^{\circ} \mathrm{C}$ followed by addition to the loading buffer containing $25 \%$ bromophenol blue, $0.25 \%$ xylene cyanol, $30 \%$ glycerol $(3 \mu \mathrm{L})$, and finally loaded on $0.8 \%$ agarose gel containing $1.0 \mu \mathrm{g} / \mathrm{mL}$ ethidium bromide. Electrophoresis was carried out at $50 \mathrm{~V}$ for $2 \mathrm{~h}$ in Tris-borate EDTA (TBE) buffer. Bands were visualized by UV light and photographed to determine the extent of DNA cleavage from the intensities of the bands using UVItec Gel Documentation System. Due corrections were made for the trace of NC DNA present in the SC DNA sample and for the low affinity of EB binding to SC DNA in comparison to the $\mathrm{NC}$ form.

Thermal denaturation experiments were carried out by monitoring the absorption of $C T$-DNA $(50 \mu \mathrm{M})$ at $260 \mathrm{~nm}$ at various temperatures in the presence $(5-10 \mu \mathrm{M})$ and absence of each complex. The melting temperature $\left(T_{m}\right.$, the temperature at which $50 \%$ of double-stranded DNA becomes singlestranded) and the curve width ( $\sigma T$, the temperature range between which $10 \%$ and $90 \%$ of the absorption increases occurred) were calculated as reported.

\section{Results and Discussion}

3.1. General Properties. The colours and other physical properties of the complexes were listed in Table 1. The complexes were highly soluble in DMSO and DMF and were slightly soluble in $\mathrm{CHCl}_{3}$.

3.2. Molar Conductance Measurements. The complexes were dissolved in acetonitrile and the molar conductivity values of $10^{-3} \mathrm{M}$ solutions at $25 \pm 2^{\circ} \mathrm{C}$ were measured and the values exhibited (Table 1). It was concluded from the observations that the complexes have molar conductivity values in the range from 21.9 to $27.7 \Omega^{-1} \mathrm{~mol}^{-1} \mathrm{~cm}^{2}$ indicating the nonionic nature of these complexes and were thus considered as nonelectrolytes. From the conductivity measurements, it was inferred that the chloride ions were coordinated to metal ions, indicating that they were ligands and not simple ions [11].

3.3. Elemental Analyses of the Complexes. Based on the metalligand ratio calculated by the analytical data and the nature of the electrolytes given by the conductance measurements, compositions were assigned for the prepared complexes. From the magnetic and conductance values, it was predicted that the complexes may have the following stoichiometries: $\left[\mathrm{CrCl}_{3}(\mathrm{DP})_{3}\right],\left[\mathrm{MnCl}_{2}(\mathrm{DP})_{4}\right],\left[\mathrm{FeCl}_{3}(\mathrm{DP})_{3}\right],\left[\mathrm{CoCl}_{2}(\mathrm{DP})_{4}\right]$, $\left[\mathrm{NiCl}_{2}(\mathrm{DP})_{4}\right],\left[\mathrm{CuCl}_{2}(\mathrm{DP})_{4}\right]$, and $\left[\mathrm{CdCl}_{2}(\mathrm{DP})_{4}\right]$.

3.4. Infrared Spectral Analysis. The ligating behaviour of 4 -N,N-dimethylaminopyridine in the isolated complexes was satisfactory and acceptable due to the stereostructure arrangement of the active donor sites present in the ligand 
TABLE 2: Characteristic IR bands $\left(\mathrm{cm}^{-1}\right)$ of the ligand and its complexes.

\begin{tabular}{|c|c|c|c|c|c|c|c|c|}
\hline Compound & $\begin{array}{c}{\left[v_{s}(\mathrm{C}=\mathrm{C})+\right.} \\
(\mathrm{C}=\mathrm{N})]\end{array}$ & $\begin{array}{c}{\left[v_{a}(\mathrm{C}=\mathrm{C})+\right.} \\
(\mathrm{C}=\mathrm{N})]\end{array}$ & $\delta(\mathrm{C}=\mathrm{N})$ & $\begin{array}{c}\text { Ring } \\
\text { breathing }\end{array}$ & $\begin{array}{c}\nu(\mathrm{OH}) \\
\text { (hydrated water) }\end{array}$ & $\begin{array}{c}\delta\left(\mathrm{H}_{2} \mathrm{O}\right) \\
\text { (hydrated water) }\end{array}$ & $v(\mathrm{M}-\mathrm{N})$ & $v(\mathrm{M}-\mathrm{Cl})$ \\
\hline DP & 1410sh & $1630 \mathrm{sh}$ & $753 \mathrm{~s}$ & $1143 \mathrm{~s}$ & & - & & \\
\hline$\left[\mathrm{CrCl}_{3}(\mathrm{DP})_{3}\right]$ & $1342 \mathrm{sh}$ & $1612 \mathrm{sh}$ & $746 \mathrm{sh}$ & $1170 \mathrm{~s}$ & $3439 \mathrm{br}$ & $816 \mathrm{~m}$ & $507 \mathrm{~s}$ & 399sh \\
\hline$\left[\mathrm{MnCl}_{2}(\mathrm{DP})_{4}\right]$ & $1326 s$ & $1612 \mathrm{br}$ & $706 \mathrm{~s}$ & $1188 \mathrm{~s}$ & $3458 \mathrm{sh}$ & $811 \mathrm{~m}$ & $472 \mathrm{sh}$ & $397 \mathrm{~s}$ \\
\hline$\left[\mathrm{FeCl}_{3}(\mathrm{DP})_{3}\right]$ & $1309 \mathrm{~s}$ & $1559 \mathrm{~s}$ & $724 \mathrm{sh}$ & $1199 \mathrm{sh}$ & $3396 \mathrm{br}$ & 826 sh & $498 \mathrm{sh}$ & $388 \mathrm{~s}$ \\
\hline$\left[\mathrm{CoCl}_{2}(\mathrm{DP})_{4}\right]$ & $1308 \mathrm{sh}$ & $1609 \mathrm{sh}$ & $674 \mathrm{sh}$ & $1259 \mathrm{~s}$ & $3422 \mathrm{sh}$ & $802 \mathrm{~m}$ & $432 \mathrm{sh}$ & $390 \mathrm{~m}$ \\
\hline$\left[\mathrm{NiCl}_{2}(\mathrm{DP})_{4}\right]$ & $1383 \mathrm{sh}$ & $1614 \mathrm{br}$ & $748 s$ & $1178 \mathrm{~m}$ & $3427 \mathrm{sh}$ & $811 \mathrm{~m}$ & $495 \mathrm{~m}$ & $398 \mathrm{sh}$ \\
\hline$\left[\mathrm{CuCl}_{2}(\mathrm{DP})_{4}\right]$ & $1390 \mathrm{~s}$ & $1616 \mathrm{sh}$ & $759 \mathrm{sh}$ & $1241 \mathrm{sh}$ & $3466 \mathrm{sh}$ & $808 \mathrm{~m}$ & $456 \mathrm{~m}$ & $372 s$ \\
\hline$\left[\mathrm{CdCl}_{2}(\mathrm{DP})_{4}\right]$ & $1381 \mathrm{br}$ & $1612 \mathrm{br}$ & $715 \mathrm{~s}$ & 1211sh & $3445 \mathrm{sh}$ & $823 \mathrm{sh}$ & 470sh & $380 \mathrm{~s}$ \\
\hline
\end{tabular}

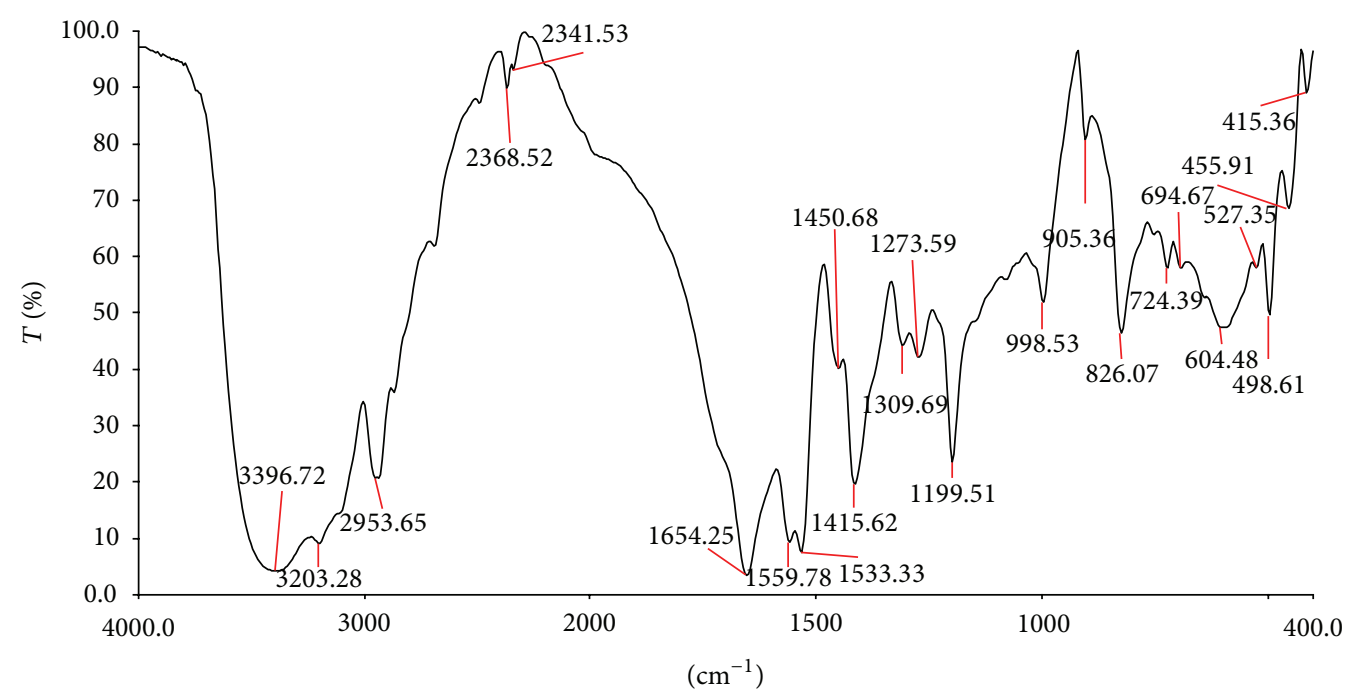

FIgURE 1: IR spectrum of $\left[\mathrm{FeCl}_{3}(\mathrm{DP})_{3}\right]$ complex.

and their deviated positions from each other's. This structural elevation of the ligand DP can express both the monodentate and bidentate attachment through the more electron dense group of it [12]. Although the ring nitrogen was more basic in comparison to the amine nitrogen, it is necessary to clarify whether the coordination occurs through the ring nitrogen or amine nitrogen or both of them in a bidentate manner. When the amine nitrogen is involved in complex formation, drastic changes occur in the vibrational wave numbers of the amine group ( $\mathrm{NH}$ stretching and bending modes shift to lower wave numbers and $\mathrm{NH}$ wagging mode shift to higher wave numbers). On the other, hand when the pyridine ring nitrogen was involved in complex formation, pyridine ring breathing and deformation vibrational modes increase in value due to coupling with $\mathrm{M}-\mathrm{N}$ (pyridine) bond vibrations and alterations of the force field [13]. The change in vibrational wave numbers of complexes from ligand supports the coordination of DP through the pyridine ring nitrogen.

Pyridine ring vibrations of free DP at $1028 \mathrm{~cm}^{-1}$ (ring breathing mode) were shifted to higher frequencies in the spectra of the complexes (Table 2). The higher shift observed in $\nu \mathrm{N}-\mathrm{C}$ and $\delta \mathrm{N}-\mathrm{C}$ bands supports the coordination of pyridine ring. The pyridine ring breathing and deformation in frequency band intensities were changed to higher positions during complex formation, instructing that the pyridine ring nitrogen was coordinated. These bands shift to lower wave numbers in the complexes due to the coordination of the ring nitrogen. The DP shows strong bands at $1465 \mathrm{~cm}^{-1}$ and $1143 \mathrm{~cm}^{-1}$ which were assigned to asymmetric and symmetric stretching of pyridine ring $\left[\nu_{s}(\mathrm{C}=\mathrm{C})+(\mathrm{C}=\mathrm{N})\right]$. The lower shift observed in the pyridine ring band $\nu_{a}(\mathrm{C}=\mathrm{C})+(\mathrm{C}=\mathrm{N})$ that appeared around $1400 \mathrm{~cm}^{-1}$ in the complex (Figure 1) supports their involvement in coordination in its neutral state [14].

Also a minor negative shift observed for $\nu(C=C)$ supports their being sided out from complexation. The water of hydration caused a small broadband in the higher field area $\left(3480 \mathrm{~cm}^{-1}\right)$ followed by another band at $890-810 \mathrm{~cm}^{-1}$. New bands appearing in the range of 541-526 and 304-297 $\mathrm{cm}^{-1}$ region of the IR spectra of the complexes (not present in the spectrum of the free ligands) were attributed to $v(\mathrm{M}-\mathrm{N})$ and $\nu(\mathrm{M}-\mathrm{Cl})$ vibrations, respectively.

The complexes show $v(\mathrm{M}-\mathrm{Cl})$ band around $300 \mathrm{~cm}^{-1}$, which is similar to its assignment for terminal chloroligands. There is no strong bands observed around $320 \mathrm{~cm}^{-1}$ together 
TABLE 3: Electronic spectral data and ligand field parameters of complexes.

\begin{tabular}{lccccccccccc}
\hline Complex & $\nu_{1}$ & $\nu_{2}$ & $\nu_{3}$ & $B$ & $B^{\prime}$ & $\beta$ & $\beta \%$ & $\nu_{2} / \nu_{1}$ & $\nu_{3} / \nu_{2}$ & $\begin{array}{c}\text { LFSE } \\
\mathrm{kcal} \mathrm{mol}\end{array}$ \\
\hline$\left[\mathrm{CrCl}_{3}(\mathrm{DP})_{3}\right]$ & 16286 & 22727 & 31446 & 1168 & 964 & 0.825 & 17.50 & 1.39 & 1.38 & 37.43 \\
{$\left[\mathrm{MnCl}_{2}(\mathrm{DP})_{4}\right]$} & 16864 & 26925 & 31625 & 1148 & 952 & 0.829 & 17.10 & 1.61 & 1.17 & 34.86 \\
{$\left[\mathrm{FeCl}_{3}(\mathrm{DP})_{3}\right]$} & 15423 & 21428 & - & 1060 & 912 & 0.860 & 14.00 & 1.38 & - & 36.78 \\
{$\left[\mathrm{CoCl}_{2}(\mathrm{DP})_{4}\right]$} & 19623 & 25122 & 28326 & 1104 & 920 & 0.833 & 16.70 & 1.28 & 1.12 & 27.17 \\
{$\left[\mathrm{NiCl}_{2}(\mathrm{DP})_{4}\right]$} & 14626 & 17815 & 23679 & 1070 & 892 & 0.833 & 16.70 & 1.21 & 1.32 & 30.82 \\
{$\left[\mathrm{CuCl}_{2}(\mathrm{DP})_{4}\right]$} & 12681 & 23616 & - & 1056 & 860 & 0.814 & 18.60 & 1.86 & - & 33.36 \\
\hline
\end{tabular}

with bands around $160 \mathrm{~cm}^{-1}$ that have ruled out the possibility of the bridging mode [15].

3.5. Electronic Spectral Analysis. The Cr(III) complex exhibits three bands at $31,446 \mathrm{~cm}^{-1}, 22,727 \mathrm{~cm}^{-1}$, and $16,286 \mathrm{~cm}^{-1}$ assigned to ${ }^{4} \mathrm{~A}_{2} \mathrm{~g}(\mathrm{~F}) \rightarrow{ }^{4} \mathrm{~T}_{1} \mathrm{~g}(\mathrm{P}),{ }^{4} \mathrm{~A}_{2} \mathrm{~g}(\mathrm{~F}) \rightarrow{ }^{4} \mathrm{~T}_{1} \mathrm{~g}(\mathrm{~F})$, and ${ }^{4} \mathrm{~A}_{2} \mathrm{~g}(\mathrm{~F}) \rightarrow{ }^{4} \mathrm{~T}_{2} \mathrm{~g}(\mathrm{P})$ transitions, respectively. The magnetic moment (3.72 B.M.) was well within the range for the three unpaired electrons. The electronic spectral bands and the magnetic moment strongly support the octahedral geometry around the $\mathrm{Cr}$ (III) ion. The inter electronic repulsion parameter of the complex $B^{\prime}\left(946 \mathrm{~cm}^{-1}\right)$ was found to be lower than the free ion value of $1168 \mathrm{~cm}^{-1}$, suggesting the delocalisation of coordinated ligand [16].

The diffused reflectance spectrum of the $\mathrm{Mn}(\mathrm{II})$ complex shows three bands at $16,864 \mathrm{~cm}^{-1}, 26,925 \mathrm{~cm}^{-1}$, and $31,625 \mathrm{~cm}^{-1}$ assigned to ${ }^{6} \mathrm{~A}_{1} \mathrm{~g} \rightarrow{ }^{4} \mathrm{~T}_{1} \mathrm{~g},{ }^{6} \mathrm{~A}_{1} \mathrm{~g} \rightarrow{ }^{4} \mathrm{~T}_{2} \mathrm{~g}(\mathrm{G})$, and ${ }^{6} \mathrm{~A}_{1} \mathrm{~g} \rightarrow{ }^{4} \mathrm{~T}_{2} \mathrm{~g}(\mathrm{D})$ transitions, respectively. The magnetic moment value (5.35 B.M.) supports octahedral structure. The electronic spectra of the Fe(III) complex showed strong bands at 15,423 and $21,428 \mathrm{~cm}^{-1}$. It was not possible to identify the type of the $\mathrm{d}$-d transition. This was due to a strong chargetransfer (CT) band tailing from the UV-region to the visible region. The magnetic moment of the $\mathrm{Fe}(\mathrm{III})$ complex was observed as 5.23 B.M., which is lower than the magnetic moment of the high spin octahedral complex. Generally, a tentative interpretation expects the structure of $\mathrm{Fe}$ (III) to be octahedral geometry with weak d-d transitions [17].

The magnetic moment of the Co(II) complex was observed to be 4.54 B.M. The diffused reflectance spectrum of the complex shows three characteristic peaks at $19,623 \mathrm{~cm}^{-1}$, $25,122 \mathrm{~cm}^{-1}$, and $28,326 \mathrm{~cm}^{-1}$ assigned to the transitions ${ }^{4} \mathrm{~T}_{1} \mathrm{~g}(\mathrm{~F}) \rightarrow{ }^{4} \mathrm{~T}_{2} \mathrm{~g}(\mathrm{~F}),{ }^{4} \mathrm{~T}_{1} \mathrm{~g} \rightarrow{ }^{4} \mathrm{~A}_{2} \mathrm{~g}$, and ${ }^{4} \mathrm{~T}_{1} \mathrm{~g}(\mathrm{~F}) \rightarrow{ }^{4} \mathrm{~T}_{1} \mathrm{~g}(\mathrm{P})$ transitions, respectively, indicating a high-spin octahedral geometry. The assignment of octahedral geometry to this complex was further supported by its $v_{2} / \nu_{1}$ which lies at 1.28. The CFSE values of $\mathrm{Co}(\mathrm{II})$ complex were calculated from transition energy ratio diagram using the $v_{3} / \nu_{2}$ ratio [17]. Various ligand field parameters were calculated for the complexes and were listed in Table 3.

The $\mathrm{Ni}$ (II) complex is high spin with a room temperature magnetic moment value of 3.15 B.M. This value is in the normal range observed for octahedral $\mathrm{Ni}(\mathrm{II})$ complexes. In addition, the complex displays three bands in the solid reflectance spectrum at $v_{1}: 14,626 \mathrm{~cm}^{-1}$ for ${ }^{3} \mathrm{~A}_{2} \mathrm{~g} \rightarrow{ }^{3} \mathrm{~T}_{2} \mathrm{~g}$; $v_{2}: 17,815 \mathrm{~cm}^{-1}$ for ${ }^{3} \mathrm{~A}_{2} \mathrm{~g} \rightarrow{ }^{3} \mathrm{~T}_{1} \mathrm{~g}(\mathrm{~F})$; and $\nu_{3}: 23,679 \mathrm{~cm}^{-1}$ for ${ }^{3} \mathrm{~A}_{2} \mathrm{~g} \rightarrow{ }^{3} \mathrm{~T}_{1} \mathrm{~g}(\mathrm{P})$ transitions. The spectrum also shows a band at $37,173 \mathrm{~cm}^{-1}$ that may be attributed to L-MCT charge transfer [15]. The 10 Dq values $13,987 \mathrm{~cm}^{-1}$ confirm the octahedral configuration of the complex.

The spectrum of $\mathrm{Cu}$ (II) complex consists of broad, low intensity shoulder bands centred at $12,681 \mathrm{~cm}^{-1}$ and $23,616 \mathrm{~cm}^{-1}$. The ${ }^{2} \mathrm{Eg}$ and ${ }^{2} \mathrm{~T}_{2}$ g states of the octahedral $\mathrm{Cu}$ (II) ion $\left(\mathrm{d}^{9}\right)$ split under the influence of the tetragonal distortion that causes three transitions ${ }^{2} \mathrm{~B}_{1} \mathrm{~g} \rightarrow{ }^{2} \mathrm{~B}_{2} \mathrm{~g} ;{ }^{2} \mathrm{~B}_{1} \mathrm{~g} \rightarrow{ }^{2} \mathrm{Eg}$; and ${ }^{2} \mathrm{~B}_{1} \mathrm{~g} \rightarrow{ }^{2} \mathrm{~A}_{1} \mathrm{~g}$. It could be concluded that all the three transitions lie within the two broad envelopes centred at the same range. The magnetic moment of 1.82 B.M. falls within the range normally observed for octahedral $\mathrm{Cu}$ (II) complex and a moderately intense peak observed at $22,469 \mathrm{~cm}^{-1}$ was due to L-MCT.

The diamagnetic Cd(II) complex did not show any d-d bands and its spectrum was dominated only by a charge transfer band. The charge transfer band at $340 \mathrm{~nm}$ was assigned to the transition ${ }^{2} \mathrm{Eg} \rightarrow{ }^{2} \mathrm{~T}_{2} \mathrm{~g}$ possibly in an octahedral environment. On the basis of the above observations, an octahedral geometry could be suggested for all the complexes [15].

3.6. ${ }^{1} H$ NMR Spectra Studies. The ${ }^{1} \mathrm{H}$ NMR spectra of the free DP and its complexes were recorded in DMSO-d and the peaks were listed in Table 4. The DP shows the signals for the aromatic protons at: $\delta 6.54\left(\mathrm{H}_{2}\right.$ and $\left.\mathrm{H}_{6}\right)$ and $8.32\left(\mathrm{H}_{3}\right.$ and $\left.\mathrm{H}_{5}\right)$; also the amine (methyl) proton appeared at 3.12. However, these signals were shifted downfield in the complexes by 0.06-0.19 ppm for the aromatic protons. The spectrum also shows a single peak at $6 \mathrm{ppm}$, which was attributed to the $\mathrm{N}\left(\mathrm{CH}_{3}\right)_{2}$ groups. This signal was shifted to the upfield in the $\mathrm{Cd}(\mathrm{II})$ complex by $0.22 \mathrm{ppm}$. The appearance of $\mathrm{CH}_{3}$ groups in the complex were suggested that the coordination was impossible through the amine nitrogen. This indicates that the DP was coordinated with the metal ions through ring nitrogen [18].

3.7. ${ }^{13} \mathrm{C}$ NMR Spectra Studies. The ${ }^{13} \mathrm{C}$ NMR spectrum of the DP shows three peaks at $150.34,107.56$, and $154.38 \mathrm{ppm}$ which were due to $\left(\mathrm{C}_{2,6}\right),\left(\mathrm{C}_{3,5}\right)$, and $\mathrm{C}_{4}$, respectively. In the complexes, the $\mathrm{C}_{4}$ signal that was adjacent to the coordination site was shifted to up-field by $9.42 \mathrm{ppm}$ due to deshielding. Also, the spectrum of the DP shows three signal protons at 
TABLE $4:{ }^{1} \mathrm{H}$ NMR chemical shift ( $\left.\delta \mathrm{ppm}\right)$ of the free ligand and its complexes.

\begin{tabular}{lccc}
\hline Compound & $\mathrm{N}\left(\mathrm{CH}_{3}\right)_{2}$ & $\mathrm{H}_{2}$ and $\mathrm{H}_{6}$ & $\mathrm{H}_{3}$ and $\mathrm{H}_{5}$ \\
\hline $\mathrm{DP}$ & 3.12 & 6.54 & 8.32 \\
{$\left[\mathrm{Cd}(\mathrm{CL})_{2}(\mathrm{DP})_{4}\right]$} & 3.34 & 6.48 & 8.13 \\
\hline
\end{tabular}

$159.80\left(\mathrm{C}_{2,6}\right)$ and $118.30\left(\mathrm{C}_{3,5}\right)$ because of the very strong overlap between $\left(\mathrm{C}_{3}\right.$ and $\left.\mathrm{C}_{5}\right)$ and $\left(\mathrm{C}_{2}\right.$ and $\left.\mathrm{C}_{6}\right)$ peaks. However, a significant shift to the down-field by 7.48 ppm was observed on Cd(II) complex in amine carbon (methyl group). These signals support the involvement of pyridine ring nitrogen in complexation [19].

3.8. ESR Spectral Analysis. The x-band ESR spectrum of the copper complex was recorded in DMSO at 300 and $77 \mathrm{~K}$ (Figure 2). The $g$ tensor values of copper complex are used to derive the ground state values. In octahedral complexes, the unpaired electron lies in the $\mathrm{dx}^{2}-\mathrm{y}^{2}$ orbitals giving ${ }^{2} \mathrm{~B}_{1} \mathrm{~g}$ as the ground state. From the observed values, it was clear that $A_{\|}=128>A_{\perp}=56 ; g_{\|}=2.42>g_{\perp}=2.13>$ 2.0023; and the EPR parameters of the complex coincide well with related systems which suggests that the complex has octahedral geometry (tetragonal distortion) and the system was axially symmetric. According to Hathaway; if the value of $G\left(G=g_{\|}-2 / g_{\perp}-2\right)$ is larger than four, the exchange interaction is negligible because the local tetragonal axes are misaligned [20]. For the present complex, the $G$ value is 3.4, which suggests that the local tetragonal axis is aligned parallel or slightly misaligned and is consistent with $\mathrm{dx}^{2}-\mathrm{y}^{2}$ ground state.

The in plane $\sigma$-bonding covalence parameter, $\alpha^{2}$ was found to be 0.82 , which indicates that the complex has a covalent in character. The out-of-plane $\pi$-bonding $\left(\gamma^{2}\right)$ and in-plane $\pi$-bonding $\left(\beta^{2}\right)$ parameters were also calculated. The observed $\beta^{2}(0.70)$ and $\gamma^{2}(1.34)$ values indicate that there was a substantial interaction in the in-plane bonding, whereas the out-of-plane bonding was completely ionic. This was also confirmed by the values of orbital reduction factors $\left(K_{\|}\right.$and $\left.K_{\perp}\right)$. In the case of pure $\sigma$-bonding, $K_{\|} \sim K_{\perp}$ implies considerable in-plane $\pi$-bonding, while $K_{\|}>K_{\perp}$ implies outof-plane $\pi$-bonding. In the present study, the observed order for the copper complex was $K_{\|}(0.56)<K_{\perp}(1.072)$ which indicates the presence of significant in-plane $\pi$-bonding [20, 21].

3.9. Thermoanalytical Studies. The proposed decomposition stages, temperature ranges, decomposition products, and the calculated and found weight loss percentages of the complexes were presented in Table 5. In most of the investigated complexes, the first decomposition stage was the removal of hydrated water molecules. The kinetic parameters for the thermal behaviour of the complexes were calculated and displayed in Table 6.

The gradual degradation stages representing in TGA, DTA, and DTG curves for $\left[\mathrm{CrCl}_{3}(\mathrm{DP})_{3}\right]$ complex started with decomposition at $55.17^{\circ} \mathrm{C}$ reflecting the thermal instability

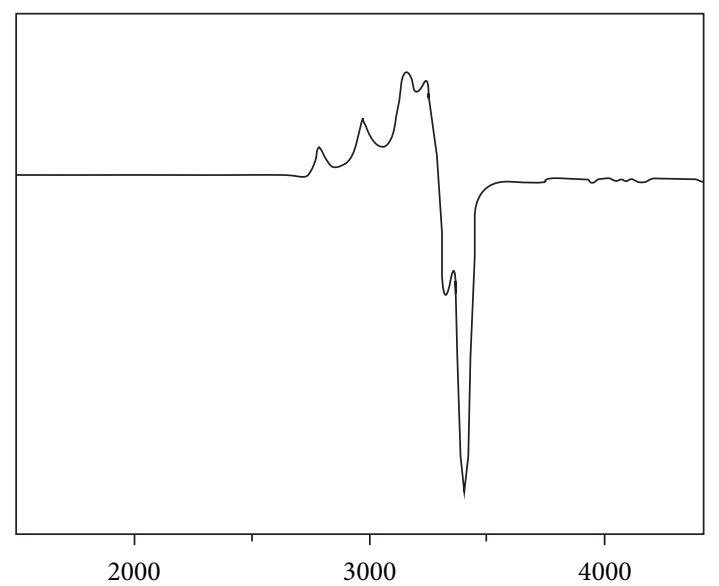

FIGURE 2: EPR spectrum of $\left[\mathrm{CuCl}_{2}(\mathrm{DP})_{4}\right]$ complex.

referring to the hydrated water molecules expelled in the first step by 3.52 (calcd. 3.4\%) weight loss. The removal of $\mathrm{Cl}_{2}$ molecule by 20.27 (calcd. 20.35\%) in the second step started was carried out at $174.7^{\circ} \mathrm{C}$. The removal of $\left(\mathrm{CH}_{3}\right)_{2} \mathrm{NH}$ molecules at the third step started at $350.5^{\circ} \mathrm{C}$ by 25.76 (calcd. 25.86\%) weight losses. The $\mathrm{C}_{5} \mathrm{H}_{4} \mathrm{~N}$ organic moiety was expelled completely at $779.4^{\circ} \mathrm{C}$ as the final part by 40.72 (calcd. 40.83\%) weight losses. The residual part represents in CrO by 13.42 (calcd. 13.71\%) weights.

The gradual degradation stages for $\left[\mathrm{MnCl}_{2}(\mathrm{DP})_{4}\right] \mathrm{com}$ plex started at $56.17^{\circ} \mathrm{C}$ was attributed to the dehydration by 2.52 (calcd. 2.86\%) weight loss. The removal of $\mathrm{Cl}_{2}$ occurred in the subsequent decomposition started at $171.42^{\circ} \mathrm{C}$ by 11.21 (calcd. 11.93\%) weight loss. The removal of major organic part in the coordinated compound $\left[\left(\mathrm{CH}_{3}\right)_{2} \mathrm{NH}+\mathrm{C}_{5} \mathrm{H}_{4} \mathrm{~N}\right]$ happened in the continuous steps started as 350.91 and $580.12^{\circ} \mathrm{C}$ by 14.33 (calcd. $15.11 \%$ ) and 47.12 (calcd. $47.92 \%$ ) weight loss, respectively. The final residue was $\mathrm{MnO}$ polluted with carbon.

The thermoanalytical profile of the $\left[\mathrm{CoCl}_{2}(\mathrm{DP})_{4}\right] \mathrm{com}$ plex showed a mass loss in the range $52.6-90.8^{\circ} \mathrm{C}$, this initial decomposition reflecting the thermal instability due to the hydrated water molecules by a weight loss $2.46 \%$ (calc.2.40\%). This was further confirmed by the broad peak $\left(\Delta t_{\min }=85^{\circ} \mathrm{C}\right)$ on DTA which corresponds to the dehydration. The second step of the decomposition occurs between 190 and $325^{\circ} \mathrm{C}$ with a $11.56 \%$ (calc. $11.23 \%$ ) mass loss that corresponds to the elimination of chloride ligand. A broad exothermic peak between 300 and $350^{\circ} \mathrm{C}\left(\Delta t_{\max }=260^{\circ} \mathrm{C}\right)$ on the DTA curve (Figure 3 ) was attributed to the elimination of the ligand. The final steps reveal the removal of the organic ligand by two-stage decomposition between $485-670^{\circ} \mathrm{C}$ and $720-990^{\circ} \mathrm{C}\left[\left(\mathrm{CH}_{3}\right)_{2} \mathrm{NH}+\mathrm{C}_{5} \mathrm{H}_{4} \mathrm{~N}\right]$ by 15.63 (calc. $15.43 \%$ ) and 47.48 (calc. $48.46 \%$ ) weight loss. The mass of the final residue of $22.87 \%$ (calculated $22.48 \%$ ) corresponds to CoO. The DTG curve of the complex displays three peaks at 180,570 , and $872^{\circ} \mathrm{C}$. These peaks were attributed to the decomposition of the chloride and organic ligands. The exothermic peaks at 430 and $685^{\circ} \mathrm{C}$ on the DTA curve were consigned to the burning of the organic residue formed in the previous stage [22]. 
TABLE 5: Thermogravimetric data of the investigated complexes.

\begin{tabular}{|c|c|c|c|c|c|}
\hline Complex & Temp. range $\left({ }^{\circ} \mathrm{C}\right)$ & DTG peak $\left({ }^{\circ} \mathrm{C}\right)$ & $\begin{array}{l}\text { Decomposed } \\
\text { assignments }\end{array}$ & $\begin{array}{c}\text { Weight loss \% } \\
\text { (calcd.\%) }\end{array}$ & $\begin{array}{c}\text { Residual and weight } \\
\% \text { (calcd.\%) }\end{array}$ \\
\hline \multirow{4}{*}[\mathrm{CrCl}_{3}(\mathrm{DP})_{3}]{} & $35-170$ & 42.2 & $-\mathrm{H}_{2} \mathrm{O}$ & $3.49(3.4)$ & \\
\hline & $170-350$ & 265.8 & $-\mathrm{Cl}_{2}$ & $19.21(19.35)$ & $\mathrm{Cr}_{2} \mathrm{O}$ \\
\hline & $350-580$ & 455.5 & $-\mathrm{C}_{2} \mathrm{H}_{6} \mathrm{~N}$ & $24.56(24.74)$ & $13.22(12.7)$ \\
\hline & $580-790$ & 680.1 & $-\mathrm{C}_{5} \mathrm{H}_{4} \mathrm{~N}$ & $39.52(39.81)$ & \\
\hline \multirow{4}{*}[\mathrm{MnCl}_{2}(\mathrm{DP})_{4}]{} & $30-160$ & 41.6 & $-\mathrm{H}_{2} \mathrm{O}$ & $2.86(2.52)$ & \\
\hline & $160-330$ & 245 & $-\mathrm{Cl}_{2}$ & $11.12(11.53)$ & $\mathrm{MnO}$ \\
\hline & $330-600$ & 435 & $-\mathrm{C}_{2} \mathrm{H}_{6} \mathrm{~N}$ & $14.31(15.11)$ & $24.89(23.92)$ \\
\hline & $600-800$ & 640 & $-\mathrm{C}_{5} \mathrm{H}_{4} \mathrm{~N}$ & $46.82(46.92)$ & \\
\hline \multirow{4}{*}[\mathrm{CoCl}_{2}(\mathrm{DP})_{4}]{} & $50-90$ & 85 & $-\mathrm{H}_{2} \mathrm{O}$ & $2.46(2.40)$ & \\
\hline & $190-325$ & 180 & $-\mathrm{Cl}_{2}$ & $11.56(11.23)$ & $\mathrm{CoO}$ \\
\hline & $485-670$ & 570 & $-\mathrm{C}_{2} \mathrm{H}_{6} \mathrm{~N}$ & $15.63(15.43)$ & $22.87(22.48)$ \\
\hline & 710-990 & 872 & $-\mathrm{C}_{5} \mathrm{H}_{4} \mathrm{~N}$ & $47.48(48.46)$ & \\
\hline \multirow{4}{*}[\mathrm{NiCl}_{2}(\mathrm{DP})_{4}]{} & $35-130$ & 35.5 & $-\mathrm{H}_{2} \mathrm{O}$ & $2.88(2.65)$ & \\
\hline & $154-268$ & 204.8 & $-\mathrm{Cl}_{2}$ & $12.65(12.54)$ & $\mathrm{NiO}$ \\
\hline & $269-488$ & 347.9 & $-\mathrm{C}_{2} \mathrm{H}_{6} \mathrm{~N}$ & $14.46(14.87)$ & $22.98(22.61)$ \\
\hline & $490-675$ & 575.7 & $-\mathrm{C}_{5} \mathrm{H}_{4} \mathrm{~N}$ & $47.03(47.33)$ & \\
\hline \multirow{4}{*}[\mathrm{CuCl}_{2}(\mathrm{DP})_{4}]{} & $30-130$ & 35.5 & $-\mathrm{H}_{2} \mathrm{O}$ & $2.39(2.28)$ & \\
\hline & $112-234$ & 168.8 & $-\mathrm{Cl}_{2}$ & $10.83(10.92)$ & $\mathrm{CuO}$ \\
\hline & $235-429$ & 323.9 & $-\mathrm{C}_{2} \mathrm{H}_{6} \mathrm{~N}$ & $10.82(10.91)$ & $32.64(32.54)$ \\
\hline & $528-787$ & 681.3 & $-\mathrm{C}_{5} \mathrm{H}_{4} \mathrm{~N}$ & $43.32(43.34)$ & \\
\hline \multirow{4}{*}[\mathrm{CdCl}_{2}(\mathrm{DP})_{4}]{} & $30-110$ & 65 & $-\mathrm{H}_{2} \mathrm{O}$ & $2.63(2.42)$ & \\
\hline & $110-165$ & 130 & $-\mathrm{Cl}_{2}$ & $18.25(18.03)$ & $\mathrm{CdO}$ \\
\hline & $170-420$ & 310,390 & $-\mathrm{C}_{2} \mathrm{H}_{6} \mathrm{~N}$ & $19.63(19.84)$ & $25.01(25.35)$ \\
\hline & $480-990$ & 681 & $-\mathrm{C}_{5} \mathrm{H}_{4} \mathrm{~N}$ & $34.48(34.36)$ & \\
\hline
\end{tabular}

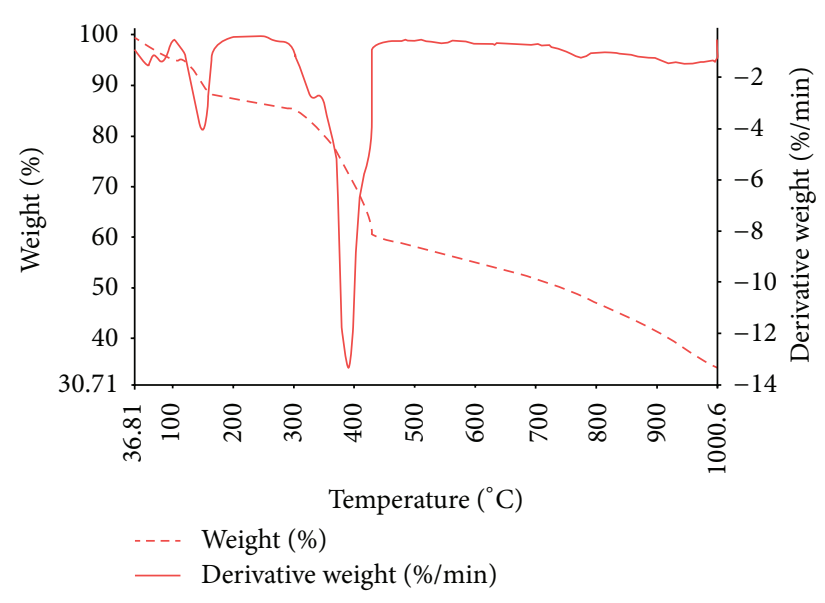

(a)

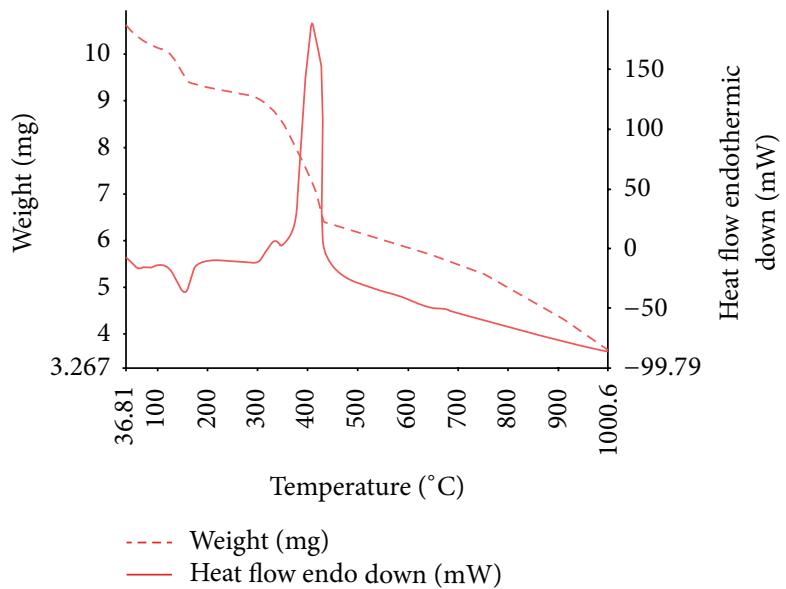

(b)

Figure 3: The TG, DTG, and DTA curves of $\left[\mathrm{CoCl}_{2}(\mathrm{DP})_{4}\right]$ complex.

The gradual degradation stages representing in TG and DTG curves for $\left[\mathrm{NiCl}_{2}(\mathrm{DP})_{4}\right]$ complex started at $40^{\circ} \mathrm{C}$ for the removal of hydrated water molecule by $2.88 \%$ (calcd. $2.45 \%$ ) and then at $154.1^{\circ} \mathrm{C}$ for the degradation stage after legal thermal stability was attributed to the removal of $\mathrm{Cl}_{2}$, by
11.65 (calcd. 11.45\%) weight loss. The removal of $\left(\mathrm{CH}_{3}\right)_{2} \mathrm{NH}+$ $\mathrm{C}_{5} \mathrm{H}_{4} \mathrm{~N}$ as a whole organic moieties in the two following steps started at 269.92 and $490.15^{\circ} \mathrm{C}$ by 13.46 (calcd. $13.87 \%$ ) and 46.03 (calcd. $46.23 \%$ ) weight loss. The residual part was $\mathrm{NiO}$ by 17.25 (calcd. $18.11 \%$ ) weights. In $\left[\mathrm{CuCl}_{2}(\mathrm{DP})_{4}\right]$ complex, 
TABLE 6: Thermodynamic data of the thermal decomposition of metal complexes.

\begin{tabular}{|c|c|c|c|c|c|c|}
\hline Complex & Decomp. temp., ${ }^{\circ} \mathrm{C}$ & $E^{*} \mathrm{~kJ} \mathrm{~mol}^{-1}$ & $A, \mathrm{~s}^{-1}$ & $\Delta S^{*}, \mathrm{~kJ} \mathrm{~mol}^{-1}$ & $\Delta H^{*}, \mathrm{~kJ} \mathrm{~mol}^{-1}$ & $\Delta G^{*}, \mathrm{~kJ} \mathrm{~mol}^{-1}$ \\
\hline \multirow{4}{*}[\mathrm{CrCl}_{3}(\mathrm{DP})_{3}]{} & $35-170$ & 30.77 & $1.25 \times 10^{6}$ & -120.7 & 29.77 & 44.37 \\
\hline & $170-350$ & 55.97 & $7.51 \times 10$ & -132.7 & 53.42 & 94.04 \\
\hline & $350-580$ & 85.07 & $2.49 \times 10^{5}$ & -146.0 & 80.91 & 154.0 \\
\hline & $580-790$ & 41.11 & $7.59 \times 10^{5}$ & -138.9 & 35.68 & 126.3 \\
\hline \multirow{4}{*}[\mathrm{MnCl}_{2}(\mathrm{DP})_{4}]{} & $30-160$ & 32.45 & $2.95 \times 10^{6}$ & -116.7 & 30.99 & 51.58 \\
\hline & $160-330$ & 55.40 & $3.48 \times 10^{5}$ & -139.2 & 52.82 & 95.95 \\
\hline & $330-600$ & 158.1 & $3.44 \times 10$ & -46.83 & 154.3 & 175.9 \\
\hline & $600-800$ & 122.5 & $1.85 \times 10^{6}$ & -130.8 & 117.5 & 195.6 \\
\hline \multirow{4}{*}[\mathrm{CoCl}_{2}(\mathrm{DP})_{4}]{} & $25-150$ & 31.73 & $4.71 \times 10^{5}$ & -126.8 & 30.94 & 43.03 \\
\hline & $150-400$ & 79.35 & $4.69 \times 10^{6}$ & -116.4 & 77.10 & 108.5 \\
\hline & $400-530$ & 168.2 & $9.24 \times 10^{9}$ & -57.21 & 164.6 & 189.3 \\
\hline & $530-660$ & 219.8 & $5.15 \times 10^{12}$ & -7.24 & 214.9 & 219.2 \\
\hline \multirow{4}{*}[\mathrm{NiCl}_{2}(\mathrm{DP})_{4}]{} & $30-148$ & 38.21 & $5.92 \times 10^{6}$ & -120.7 & 37.73 & 44.68 \\
\hline & $149-250$ & 32.78 & $9.82 \times 10^{6}$ & -109.3 & 30.77 & 57.10 \\
\hline & $300-510$ & 102.9 & $3.83 \times 10^{7}$ & -101.0 & 100.0 & 135.0 \\
\hline & $511-785$ & 27.92 & $8.64 \times 10^{5}$ & -135.6 & 23.76 & 91.45 \\
\hline \multirow{4}{*}[\mathrm{CuCl}_{2}(\mathrm{DP})_{4}]{} & $30-130$ & 38.21 & $5.92 \times 10^{6}$ & -120.7 & 37.73 & 44.68 \\
\hline & $112-234$ & 32.78 & $9.82 \times 10^{6}$ & -109.3 & 30.77 & 57.10 \\
\hline & $235-429$ & 102.9 & $3.83 \times 10^{7}$ & -101.0 & 100.0 & 135.0 \\
\hline & $528-787$ & 27.92 & $8.64 \times 10^{5}$ & -135.6 & 23.76 & 91.45 \\
\hline \multirow{4}{*}[\mathrm{CdCl}_{2}(\mathrm{DP})_{4}]{} & $30-110$ & 36.27 & $5.65 \times 10^{6}$ & -112.7 & 42.73 & 53.68 \\
\hline & $110-165$ & 34.65 & $8.76 \times 10^{6}$ & -115.3 & 37.77 & 62.20 \\
\hline & $170-420$ & 98.8 & $4.80 \times 10^{7}$ & -121.0 & 99.0 & 125.80 \\
\hline & $480-990$ & 35.6 & $9.45 \times 10^{5}$ & -146.6 & 36.76 & 95.60 \\
\hline
\end{tabular}

the TG and DTG curves show three decomposition stages started at $32.4^{\circ} \mathrm{C}$ and ended at $787.04^{\circ} \mathrm{C}$. The complex reveals a relative thermal stability up to $32^{\circ} \mathrm{C}$ and followed by a sudden decomposition by a weight loss 2.09 (calcd. 2.28\%) corresponding to the elimination of hydrated water The second exothermic decomposition stage started at $235.5^{\circ} \mathrm{C}$ corresponding to the removal of $\mathrm{Cl}_{2}$ as a terminal organic moiety by 10.86 (calcd. $10.90 \%$ ) weight loss. The final degradation step is overlapped with two stages which are started at $528.6^{\circ} \mathrm{C}$ and at $718^{\circ} \mathrm{C}$ respectively which are belong to the removal of $\left(\mathrm{CH}_{3}\right)_{2} \mathrm{NH}$ and $\mathrm{C}_{5} \mathrm{H}_{4} \mathrm{~N}$ organic moieties respectively by 10.28 (calcd. 10.91\%) and 43.12 (calcd. 43.32\%) weight loss and left $\mathrm{CuO}$ as a residue polluted with carbon [23].

The thermoanalytical profile of the $\left[\mathrm{CdCl}_{2}(\mathrm{DP})_{4}\right]$ complex demonstrated a weight loss initiated at $52.6^{\circ} \mathrm{C}$. A mass loss of $2.63 \%$ (calc. $2.40 \%$ ) was observed in the range 52.6 and $110.8^{\circ} \mathrm{C}$, with the endothermic peak between $60-65^{\circ} \mathrm{C}$ $\left(\Delta t_{\text {min }}=62^{\circ} \mathrm{C}\right)$ in the DTA, which corresponds to the loss of water of crystal lattice. The second step of decomposition between 112.5 and $165.9^{\circ} \mathrm{C}$ with a mass loss of $18.25 \%$ (calc.18.03\%) was assigned to the removal of the chloride ligand. The final step has two-stage decomposition processes, pertinent to the removal of the noncoordinated part of the organic $\left(\mathrm{CH}_{3}\right)_{2} \mathrm{NH}$ ligand by 19.63 (calc.19.84\%) weight loss, continued with the slow decomposition of remaining part of the coordinated ligand by 34.48 (calc.34.36\%) weight loss. The endothermic peaks at $170,420^{\circ} \mathrm{C}$ on the DTA curve correspond to the degradation of organic moiety. The mass of the final residue corresponded to $\mathrm{CdO} 12.5 \%$ (calc. $11.3 \%$ ). The DTG curve of the complex displays that two peaks at 130 and $390^{\circ} \mathrm{C}$ were endorsed to the decomposition of the chloride and organic ligands. The exothermic peaks at $420^{\circ} \mathrm{C}$ can be assigned to the burning of the organic residue formed in the previous stage [24].

3.10. Activation Thermodynamic Parameters. In order to assess the effect of the metal ion on the thermal behaviour of the complexes, the order $n$, and the heat of activation $E^{*}$ of the various decomposition stages were determined from the TG and DTG and their activation parameters were tabulated in Table 6. It could be observed from these data that the activation energy $E^{*}$ increases with the degradation steps promulgated revealing the high stability of the remaining part of the complexes suggesting a high stability of complexes characterised by their covalence. Among the complexes, the activation energy increases in the order of $\mathrm{Cr}(\mathrm{III})<\mathrm{Mn}(\mathrm{II})<$ $\mathrm{Fe}(\mathrm{III})<\mathrm{Co}(\mathrm{II})<\mathrm{Ni}(\mathrm{II})<\mathrm{Cd}(\mathrm{II})<\mathrm{Cu}(\mathrm{II})$.

All the complexes have negative entropy $(\Delta S=-\mathrm{ve})$, indicating that the complexes were formed spontaneously by absorbing energy. A more ordered activated state of the degradation process may be possible through the chemisorptions of oxygen and other decomposition products. The negative values of the entropies of activation were compensated by the values of the enthalpies of activation, leading to almost the same values for the free energy of activation [24]. The positive $\Delta H^{*}$ for all the complexes reflects the endothermic 
<smiles></smiles>

$\mathrm{M}=\mathrm{Fe}(\mathrm{III}), \mathrm{Cr}(\mathrm{III})$<smiles></smiles>

$\mathrm{M}=\mathrm{Mn}(\mathrm{II}), \mathrm{Co}(\mathrm{II}), \mathrm{Ni}(\mathrm{II}), \mathrm{Cu}(\mathrm{II}), \mathrm{Cd}(\mathrm{II})$

Figure 4: Predicted structure of the metal complexes.

decomposition process, indicating that the formation of the complexes may be exothermic in nature.

The positive $\Delta G^{*}$ values reveal that the free energy of the final residue was higher than that of the initial compound and also the decomposition stages were nonspontaneous. From these results, it is understood that the increasing step values of $T \Delta S^{*}$ clearly override the decreasing values of $\Delta H^{*}$ therein reflecting that the rate of removal of the subsequent species will be lower than that of the preceding one [25].

3.11. Structure of the Complexes. From the various physical chemical discussions, the structures of the complexes were assigned as in Figure 4.

3.12. Antibacterial Activity. The main objective of the synthesis of any antimicrobial compound is to inhibit the microbe without harming other biological cells. For in vitro antimicrobial activity, the metal complexes were tested against the bacteria B. subtilis, S. aureus, E. coli, $P$. aeruginosa, and $P$. vulgaris. The MIC values of the compounds against the growth of microorganisms were summarised in Table 7

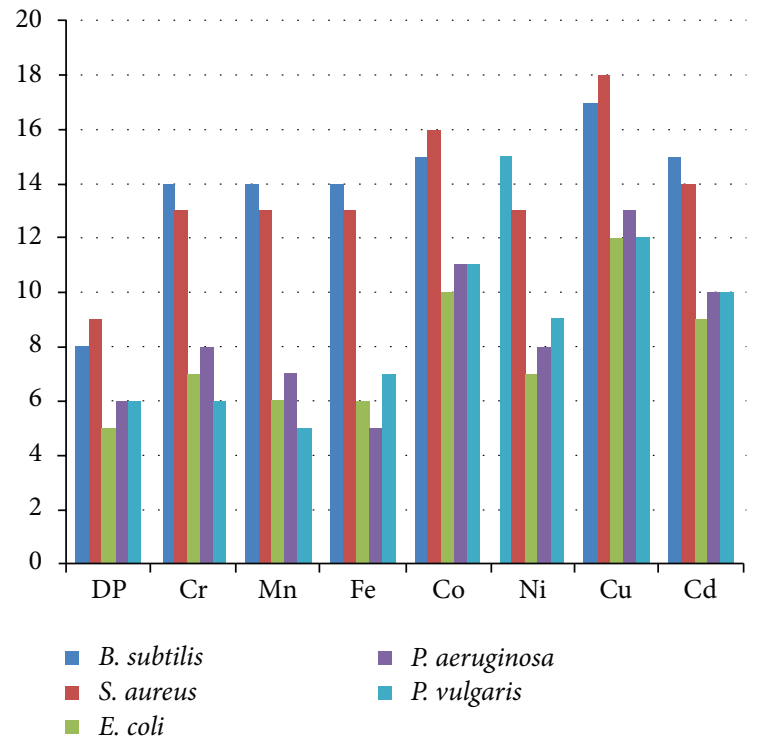

FIGURE 5: Antibacterial activity of DP and its complexes $\left(50 \mu \mathrm{g} \mathrm{mL}^{-1}\right)$.

and exhibited in Figures 5 and 6 for 100 and $200 \mu \mathrm{g} \mathrm{mL}$ concentrations, respectively.

The results of the antibacterial studies lead to the following presumptions.

The metal complexes were found to have superior biopotential in comparison to 4-N,N-dimethylamino pyridine against the same microorganism and under identical experimental conditions. This increase in biopotential property of the complexes is due to the reaction of the metal ion with the bacterial cell. Complexation considerably reduces the polarity of the metal ions because of partial sharing of its positive charge with the donor group (the ligand), and also the electron density is delocalised due to the $\pi$ back donation. Thus, the complexation process enhanced the lipophilic character of the central metal atom and hence liposolubility of the metal ion. In this way, the complexation favours the permeation of the metal ion through the lipid layers of the microorganisms' cell membrane. This permeation enhances the rate of uptake/access of the metal ion on the surface of the microorganisms cell wall. These adsorbed metal ions disturb the respiratory process of the cells, thus blocking the synthesis of proteins, and in turn deactivates enzymes responsible for respiration processes.

The antibacterial activity of the complexes decreases in the following order: $\mathrm{Cu}(\mathrm{II})>\mathrm{Cd}(\mathrm{II})>\mathrm{Ni}(\mathrm{II})>\mathrm{Co}(\mathrm{II})>$ $\mathrm{Mn}(\mathrm{II})>\mathrm{Fe}(\mathrm{III})>\mathrm{Cr}(\mathrm{III})>\mathrm{DP}$, this suggests, that the lipophilic behaviour also increases in the same order. Since all complexes (a) have the same donating atoms which were $\mathrm{N} / \mathrm{Cl}$ with the same coordination number (C.N. for each is 6) (b) and are neutral and there were no counter ions, and (c) except $\mathrm{Cr}$ (III) and $\mathrm{Fe}(\mathrm{III})$ all other have the same oxidation number in their complexes $\left(\mathrm{M}^{2+}\right)$; therefore, the more effective factors for biopotential properties could be the geometrical shape and the nature of the central atoms.

The enhanced antibacterial potential of copper(II) complex relative to the cadmium(II) complex may be due to 
TABLE 7: Antibacterial activity of the complexes-diameter of zone of inhibition (in mm).

\begin{tabular}{|c|c|c|c|c|c|c|}
\hline \multirow{2}{*}{ Compound } & \multirow{2}{*}{$\mu \mathrm{g} \mathrm{mL}^{-1}$} & \multicolumn{2}{|c|}{ Gram-positive bacteria } & \multicolumn{3}{|c|}{ Gram-negative bacteria } \\
\hline & & B. subtilis & S. aureus & E. coli & P. aeruginosa & P. vulgaris \\
\hline \multirow{2}{*}{ DP } & 100 & 08 & 09 & 05 & 06 & 06 \\
\hline & 200 & 10 & 12 & 08 & 09 & 09 \\
\hline \multirow{2}{*}[\mathrm{CrCl}_{3}(\mathrm{DP})_{3}]{} & 100 & 14 & 13 & 07 & 08 & 06 \\
\hline & 200 & 21 & 21 & 08 & 06 & 06 \\
\hline \multirow{2}{*}[\mathrm{MnCl}_{2}(\mathrm{DP})_{4}]{} & 100 & 14 & 13 & 06 & 07 & 05 \\
\hline & 200 & 17 & 16 & 07 & 08 & 07 \\
\hline \multirow{2}{*}[\mathrm{FeCl}_{3}(\mathrm{DP})_{3}]{} & 100 & 14 & 13 & 06 & 05 & 07 \\
\hline & 200 & 16 & 15 & 08 & 07 & 08 \\
\hline \multirow{2}{*}[\mathrm{CoCl}_{2}(\mathrm{DP})_{4}]{} & 100 & 15 & 16 & 10 & 11 & 11 \\
\hline & 200 & 20 & 17 & 12 & 11 & 12 \\
\hline \multirow{2}{*}[\mathrm{NiCl}_{2}(\mathrm{DP})_{4}]{} & 100 & 15 & 13 & 07 & 08 & 09 \\
\hline & 200 & 17 & 17 & 12 & 12 & 10 \\
\hline \multirow{2}{*}[\mathrm{CuCl}_{2}(\mathrm{DP})_{4}]{} & 100 & 17 & 18 & 12 & 13 & 12 \\
\hline & 200 & 22 & 21 & 12 & 14 & 13 \\
\hline \multirow{2}{*}[\mathrm{CdCl}_{2}(\mathrm{DP})_{4}]{} & 100 & 15 & 14 & 09 & 10 & 10 \\
\hline & 200 & 21 & 20 & 12 & 11 & 10 \\
\hline
\end{tabular}

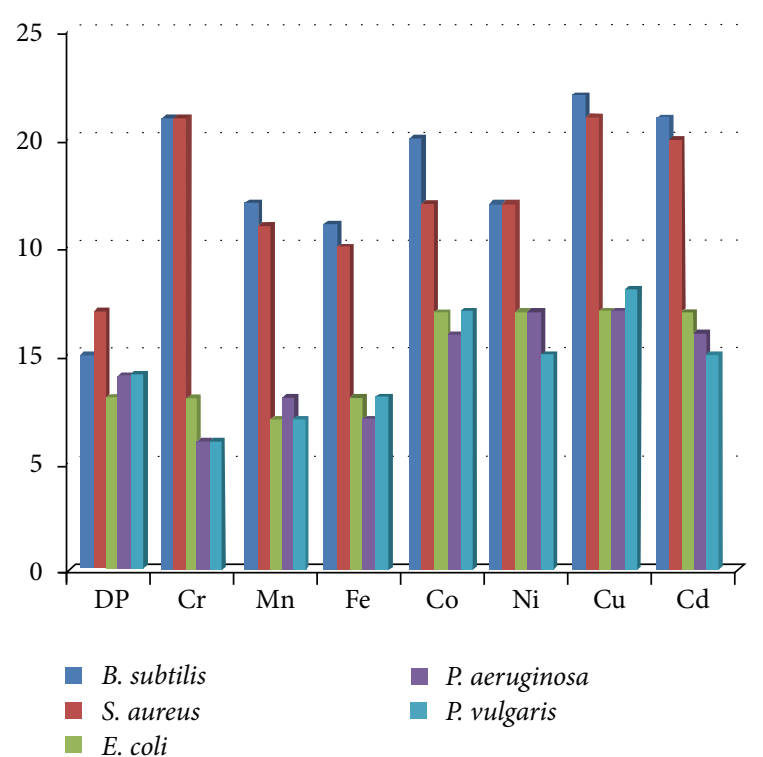

FIgURE 6: Antibacterial activity of DP and its complexes $\left(200 \mu \mathrm{g} \mathrm{mL}^{-1}\right)$.

the fact that the $\mathrm{Cu}(\mathrm{II})$-ligand bond formed by $\mathrm{Cu}(\mathrm{II})$ was stronger than the $\mathrm{Cd}(\mathrm{II})$-ligand bond which in turn may increase the lipophilic character of copper(II) compared to cadmium(II). Also the standard reduction potential of copper is high when compared to cadmium, which may be taken as an additional reason for the higher activity of copper relative to cadmium. Also, the higher antimicrobial activity of cadmium(II) complex relative to the rest of the complexes may be due to the difference in the effective nuclear charge of the metals. This means that the cadmium(II) complex increases the lipophilicity of the central atom by decreasing the effective nuclear charge (polarity) [of the Cd(II)] more than other complexes.
The complexes were effectively suppressed the Gram-positive strains than Gram-negative strains. The Gram-positive bacteria possess a thick cell wall containing many layers of peptidoglycan and teichoic acids; in contrast, the Gram-negative bacteria have relatively thin cell wall consisting of a few layers of peptidoglycan surrounded by a second lipid membrane containing lipopolysaccharides and lipoproteins. These differences in cell wall structure can produce differences in antibacterial susceptibility and some antibiotics can kill only Gram-positive bacteria and they were infective against Gram-negative pathogens [26].

It was concluded that, since each comples has different biopotential values with the same ligand, the metal seems to play a vital role in the antibacterial activity [26]. The importance of such work lies in the possibility that the new compounds might be more effective as drugs against bacteria for which a thorough investigation regarding the structure-activity relationship, toxicity, and their biological effects would be helpful in designing a potential antibacterial agent for therapeutic use.

3.13. Antifungal Activity Studies. A comparative study of MIC values of the DP and its complexes indicate that in general the metal complexes have a better fungicidal property than the free ligand. This was probably due to the improved lipophilic nature of the metal complexes, rationalised mainly on the basis of their structures possessing an additional M-N bond.

Moreover, coordination reduces the polarity of the metal ion mainly because of the partial sharing of its positive charge with the donor groups (the ligand) and also charge shared ( $\pi$ back donation) within the complex system formed during coordination. This process, in turn, increases the lipophilic nature of the central metal atom, which favours its permeation more efficiently through the lipid layer of the microorganism thus destroying them more aggressively 


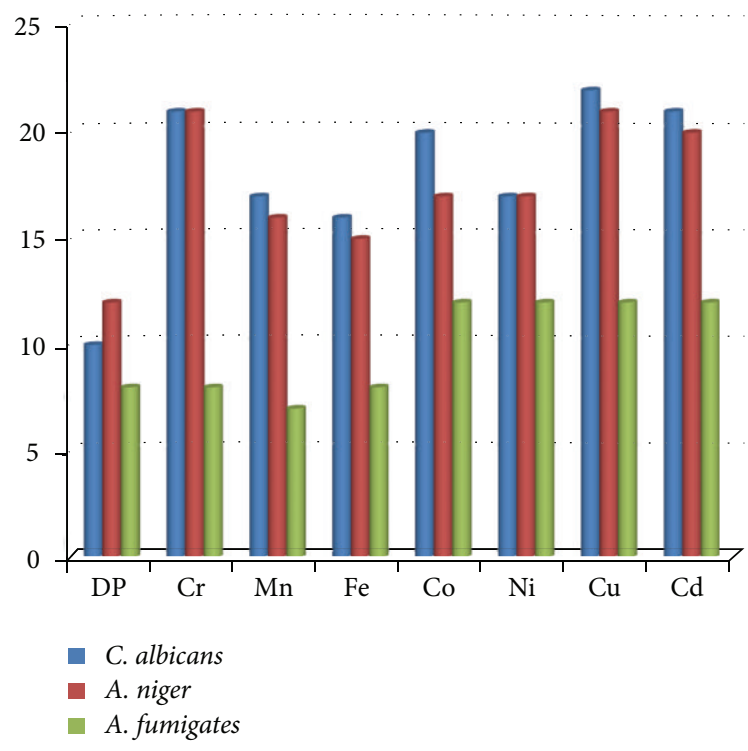

FIgure 7: Antifungal activity of DP and its complexes $\left(200 \mu \mathrm{g} \mathrm{mL}^{-1}\right)$.

(Figure 7). The toxicity of the complexes can be related to the strength of the metal-ligand bond, besides other factors such as size of the cation, receptor sites, diffusion, and a combined effect of the metal and the ligands for inactivation of the biomolecules [27].

The antifungal activity results reveal (Table 8 ) that the ligand and its $\mathrm{Mn}$ (II) and $\mathrm{Co}(\mathrm{II})$ complexes have exhibited weak activity against $A$. niger and $A$. fumigates. The diameters of the zone of inhibition of the metal complexes were ordered as follows: $\mathrm{Cu}(\mathrm{II})>\mathrm{Ni}(\mathrm{II})>\mathrm{Cd}(\mathrm{II})>\mathrm{Cr}(\mathrm{III})>\mathrm{Fe}(\mathrm{III})>$ $\mathrm{Co}(\mathrm{II})>\mathrm{Mn}$ (II). From the results of biological activity (both antifungal and antibacterial), the following inferences were made.

(i) A mutual relationship exists between the germicidal activity and the coordination environment of the metal.

(ii) The ligands also supports the transport of the active metallic moiety to the site of the action where it is released by hydrolysis.

3.14. Chemical Nuclease Cleavage Study. In order to assess the chemical nuclease activities of the $\mathrm{Co}(\mathrm{II}), \mathrm{Ni}(\mathrm{II}), \mathrm{Cd}(\mathrm{II})$, and $\mathrm{Cu}(\mathrm{II})$ complexes for DNA strand scission, CT-DNA was incubated with all the mentioned metal complexes under reaction conditions separately. The cleavage reaction can be monitored by gel-electrophoresis [28]. The delivery of metal ion to the helix locally generates oxygen or hydroxide radicals, yielding an efficient DNA cleavage reaction.

The $\left[\mathrm{CuCl}_{2}(\mathrm{DP})_{4}\right]$ complex $(30 \mu \mathrm{M}$ in $30 \mu \mathrm{L}$ volume $)$ shows $64 \%$ cleavage of the CT-DNA duplex, whereas $\left[\mathrm{CdCl}_{2}(\mathrm{DP})_{4}\right]$ complex $(30 \mu \mathrm{M}$ in $30 \mu \mathrm{L}$ volume $)$ shows $33 \%$ of cleavage on 1 hour exposure at $365 \mathrm{~nm}$ wavelength light. At the concentrations of $30 \mu \mathrm{M}$ and $40 \mu \mathrm{M}$, the $\left[\mathrm{CuCl}_{2}(\mathrm{DP})_{4}\right]$ complex was able to convert $64 \%$ and $68 \%$ of the initial
TABLE 8: Antifungal activity of the complexes and ligand-diameter of zone of inhibition $(\mathrm{mm})$.

\begin{tabular}{lccc}
\hline Compound & C. albicans & A.niger & A.fumigates \\
\hline $\mathrm{DP}$ & 11 & 10 & 13 \\
{$\left[\mathrm{CrCl}_{3}(\mathrm{DP})_{3}\right]$} & 16 & 20 & 19 \\
{$\left[\mathrm{MnCl}_{2}(\mathrm{DP})_{4}\right]$} & 12 & 13 & 13 \\
{$\left[\mathrm{FeCl}_{3}(\mathrm{DP})_{3}\right]$} & 18 & 17 & 19 \\
{$\left[\mathrm{CoCl}_{2}(\mathrm{DP})_{4}\right]$} & 16 & 14 & 17 \\
{$\left[\mathrm{NiCl}_{2}(\mathrm{DP})_{4}\right]$} & 21 & 20 & 23 \\
{$\left[\mathrm{CuCl}_{2}(\mathrm{DP})_{4}\right]$} & 24 & 23 & 24 \\
{$\left[\mathrm{CdCl}_{2}(\mathrm{DP})_{4}\right]$} & 18 & 21 & 20 \\
\hline
\end{tabular}

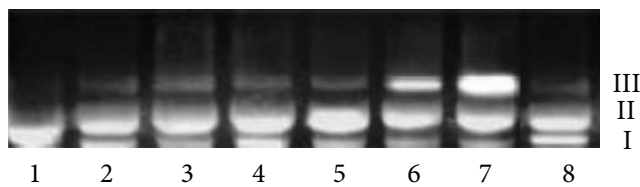

FIGURE 8: DNA photocleavage studies of 4-N,N-dimethylaminopyridine-chloride complexes. Cleavage of SC CT-DNA $(0.2 \mu \mathrm{g}$, $30 \mu \mathrm{M})$ by four metal (II) complexes $(0.30 \mathrm{mM})$ in the presence of reducing agent ascorbic acid $(0.70 \mathrm{mM})$ in $50 \mathrm{mM}$ Tris- $\mathrm{HCl} / \mathrm{NaCl}$ buffer $(\mathrm{pH}=7.2)$.

SC (Form I) to NC (nicked circular) (Form II), respectively (lanes 8 and 7). However, the nature of reactive intermediates involved in the DNA cleavage by the complexes has not been clear yet. From Figure 8, it was seen that no obvious inhibitions were observed for the $\mathrm{Cu}$ (II) complex in the presence of superoxide dismutase (SOD) (lane 6) and the results rule out the possibility of DNA cleavage by superoxide. Addition of singlet oxygen quencher $\mathrm{NaCl}$ (lane 8) does not show any appreciable effect on the chemical nuclease activity of the complex. It shows that the singlet oxygen has no role in the DNA cleavage process. The addition of EtOH (lane 8) partly diminishes the nuclease activity of the $\mathrm{Cu}$ (II) complex, these results indicate that the involvement of hydroxyl radical and/or "metal-oxo" intermediates as the reactive species in the cleavage reaction.

3.15. Thermal Denaturation Studies. The influences of DP metal complexes on the melting of CT-DNA were done to enumerate the information regarding metal ion binding on $C T$-DNA. The thermal denaturation curves for CT-DNA in the absence and in the presence of the complexes at the ratio of $[\mathrm{DNA}] /[$ complex $]=20$ were given in Figure 9, and the relevant data for all the complexes investigated in this study were summarised in Table 9. The melting studies were carried out at the DNA complex concentration of $25 \%$, and the $T_{m}$ (melting temperature) and $\sigma T$ values were determined by monitoring the absorbance of DNA (within the temperature range at which $10 \%$ and $90 \%$ of the absorption increase occurred) at $260 \mathrm{~nm}$ as a function of temperature.

In the given experimental conditions, the melting temperature $\left(T_{m}\right)$ of pure CT-DNA (in the absence of addition of complexes) was found to be $70^{\circ} \mathrm{C}$. With the addition of 


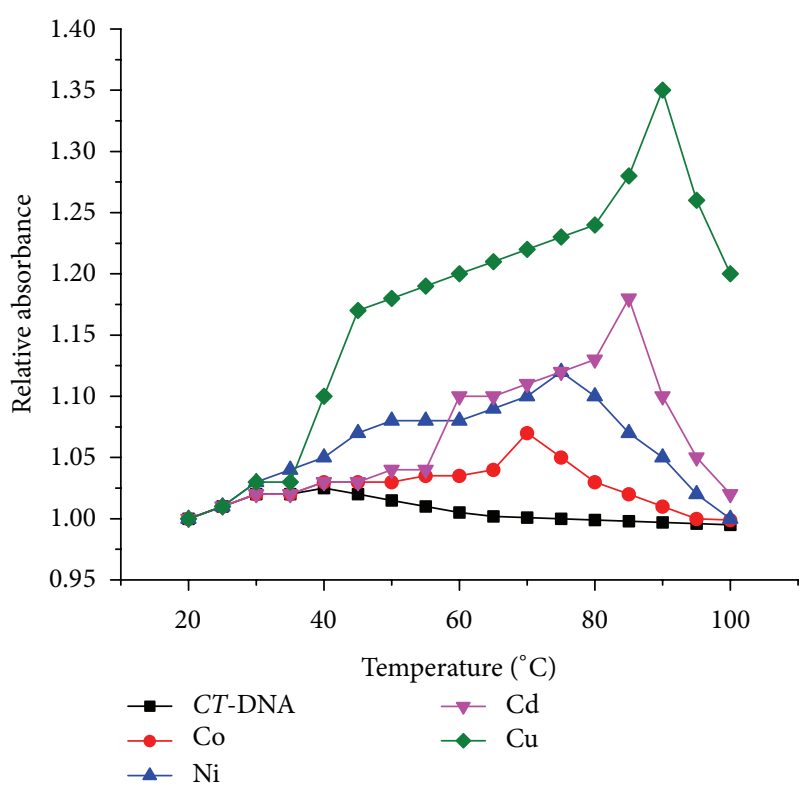

FIGURE 9: Melting curves for DNA alone and in presence of 4-N,Ndimethylaminopyridine complexes at $P / D=20$. [DNA] $=150 \mu \mathrm{M}$, [Complex $]=7.5 \mu \mathrm{M}$, and $10 \mathrm{mM}$ phosphate buffer is used in these experiments.

TABLE 9: Results of thermal denaturation, $T_{m}$, studies, [DNA]/ [complex $]=\mathrm{P} / \mathrm{D}=20$.

\begin{tabular}{lc}
\hline Complex & $T_{m} \mathrm{C}^{\circ}$ \\
\hline$C T$-DNA & 70 \\
{$\left[\mathrm{CoCl}_{2}(\mathrm{DP})_{4}\right]$} & 74 \\
{$\left[\mathrm{NiCl}_{2}(\mathrm{DP})_{4}\right]$} & 76 \\
{$\left[\mathrm{CuCl}_{2}(\mathrm{DP})_{4}\right]$} & 86 \\
{$\left[\mathrm{CdCl}_{2}(\mathrm{DP})_{4}\right]$} & 80 \\
\hline
\end{tabular}

complexes, under similar conditions the melting temperature $\left(T_{m}\right)$ of the CT-DNA was increased by $4,6,16$, and $10^{\circ} \mathrm{C}$ for the $\left[\mathrm{CoCl}_{2}(\mathrm{DP})_{4}\right]\left[\mathrm{NiCl}_{2}(\mathrm{DP})_{4}\right]\left[\mathrm{CuCl}_{2}(\mathrm{DP})_{4}\right]$, and $\left[\mathrm{CdCl}_{2}(\mathrm{DP})_{4}\right]$ complexes, respectively. The influence of metal complexes on the melting curves of the CT-DNA shows that these complexes bind to DNA and thus increase the $\mathrm{H}$ bonding between the base pairs of the double strand and increasing the melting temperature of the nucleic acid. The larger effect noted for the $\left[\mathrm{CuCl}_{2}(\mathrm{DP})_{4}\right]$ complex suggests that this complex binds in an intercalative mode and the rest of the complexes by electrostatic groove mode.

3.16. Absorption Spectral Features of DNA Binding. On adding $C T$-DNA, the complexes show a decrease in molar absorptivity of the $\pi \rightarrow \pi^{*}$ absorption band indicating the insertion of the aromatic chromophores in between the base pairs of DNA; the observed trend in hypochromism reflects the trend in DNA-binding affinities of the complexes [27-30].

The electronic absorption spectra of copper complex in the absence and presence of CT-DNA were given in Figure 10. The absorption bands for the $\mathrm{Co}(\mathrm{II}), \mathrm{Ni}(\mathrm{II}), \mathrm{Cu}(\mathrm{II})$, and Cd(II) complexes show hypochromism of $15.95 \%, 16.26 \%$,

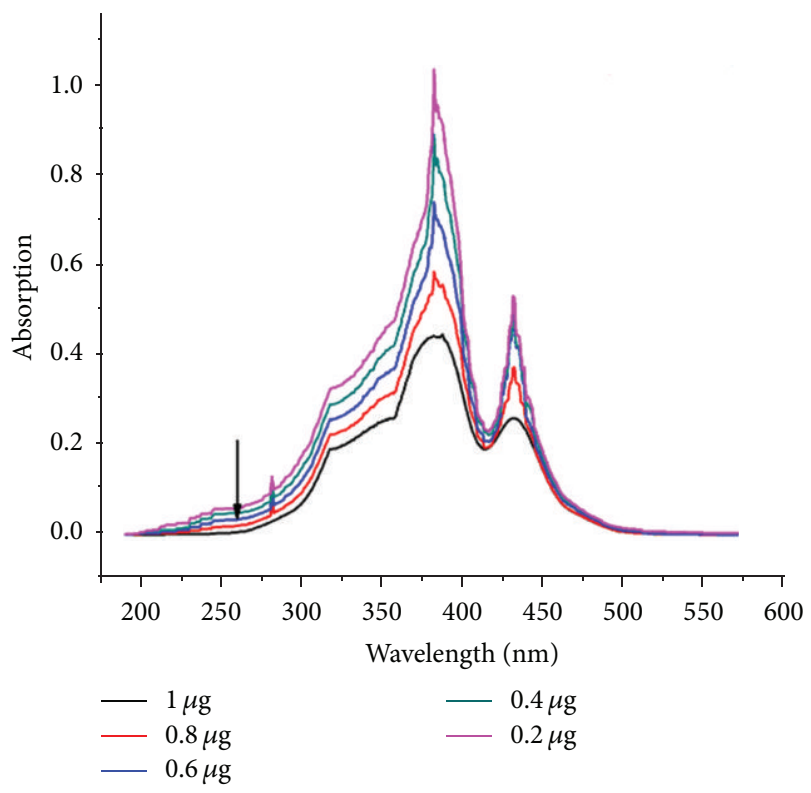

Figure 10: Absorption spectra of $\left[\mathrm{CuCl}_{2}(\mathrm{DP})_{4}\right]$ in the presence of CT-DNA; the absorption changes upon increasing CT-DNA concentration.

$32.45 \%$, and $8.25 \%$ at $366,368,368$, and $370 \mathrm{~nm}$, respectively and in each case accompanied by a small red shift by about 4, 4, 5 and $2 \mathrm{~nm}$. These absorption changes suggest that the intrinsic binding constants $\left(K_{b}\right)$ of the $\mathrm{Co}(\mathrm{II}), \mathrm{Ni}(\mathrm{II}), \mathrm{Cu}(\mathrm{II})$, and $\mathrm{Cd}(\mathrm{II})$ complexes were $3.62 \times 10^{4} \mathrm{M}^{-1}, 3.83 \times 10^{4} \mathrm{M}^{-1}$, $8.29 \times 10^{4} \mathrm{M}^{-1}$, and $2.66 \times 10^{4} \mathrm{M}^{-1}$, respectively [29].

It is interesting that these complexes regardless of their electroneutrality nature engage in interaction with the DNA duplex and exhibit strong DNA-binding affinities. This strong interaction of metal complex with the DNA may occur due to the formation of a hydrogen bonding between the metal complex and the DNA base pairs [29].

The results indicate that the binding strength of complex increases in the following order: $\mathrm{Cu}>\mathrm{Ni}>\mathrm{Co}>\mathrm{Cd}$. This suggests an intimate association of the compounds with CTDNA, and it was also likely that these compounds bind to the helix via an intercalative mode [30].

3.17. DNA Binding Electrochemical Behaviour. In the cyclic voltammogram study of the Ni(II) complex (Figure 11(a)), the emf was varied from $-2.0 \mathrm{~V}$ to $1.0 \mathrm{~V}$ at a scan rate of $50 \mathrm{~m} \mathrm{Vs}^{-1}$. During the cathodic scan, no reducible species was observed from $1.0 \mathrm{~V}$ to $-0.85 \mathrm{~V}$, and the cathodic peak observed at $-1.2 \mathrm{~V}$ may be due to the reduction of $\mathrm{Ni}$ (II) into $\mathrm{Ni}(\mathrm{I})$. In the absence of CT-DNA, the Ni(II) complex exhibits a quasireversible redox wave corresponding to $\mathrm{Ni}(\mathrm{II}) / \mathrm{Ni}(\mathrm{I})$ with $E_{\mathrm{pc}}$ and $E_{\mathrm{pa}}$ values of -0.867 and $-0.558 \mathrm{~V}$ respectively. The ratio of anodic to cathodic peak current value was found to be less than 1 and the formal electrode potentials $E_{1 / 2}$ and $\Delta E_{p}$ were calculated to be 0.309 and $-0.712 \mathrm{~V}$, respectively.

With the addition of CT-DNA to Ni(II) complex, the cathodic and anodic peaks were shifted to -0.882 and $-0.571 \mathrm{~V}$, along with a shift in the formal electrode potential 


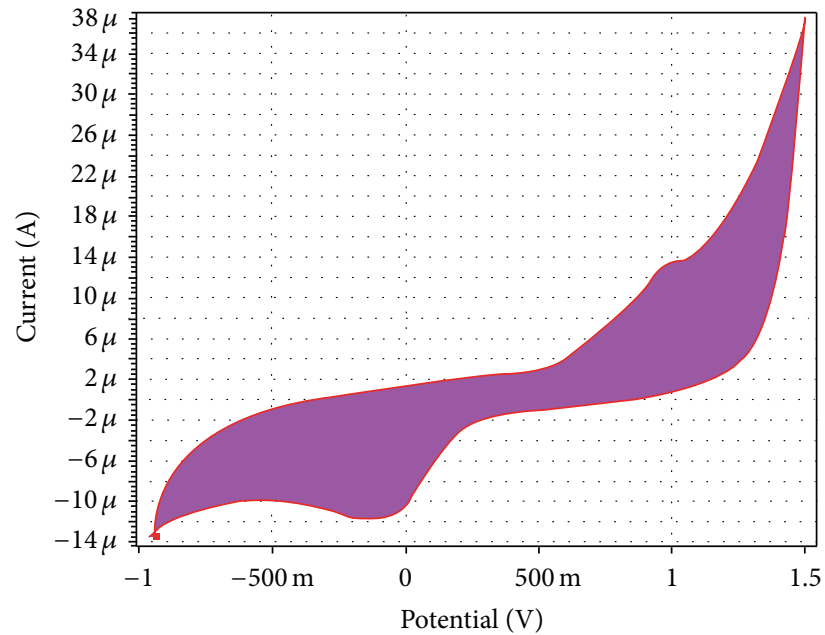

(a)

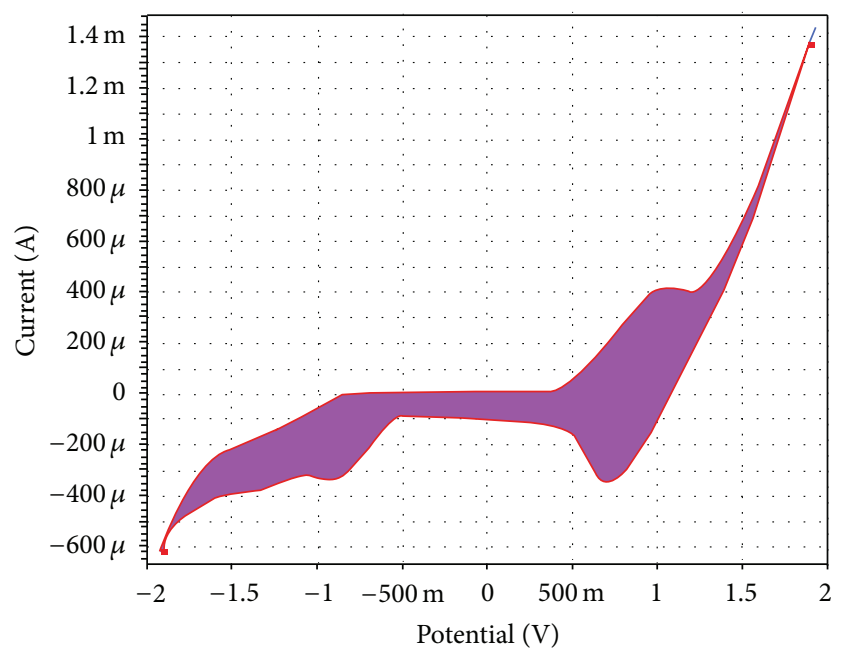

(b)

FIGURE 11: Cyclic voltammograms of the glassy carbon electrode in solutions containing $\left[\mathrm{NiCl}_{2}(\mathrm{DP})_{4}\right]$ in the (a) absence and (b) presence of CT-DNA. $V=0.1 \mathrm{Vs}^{-1}$ (versus $\mathrm{Ag} \mid \mathrm{Ag}^{+}$electrode).

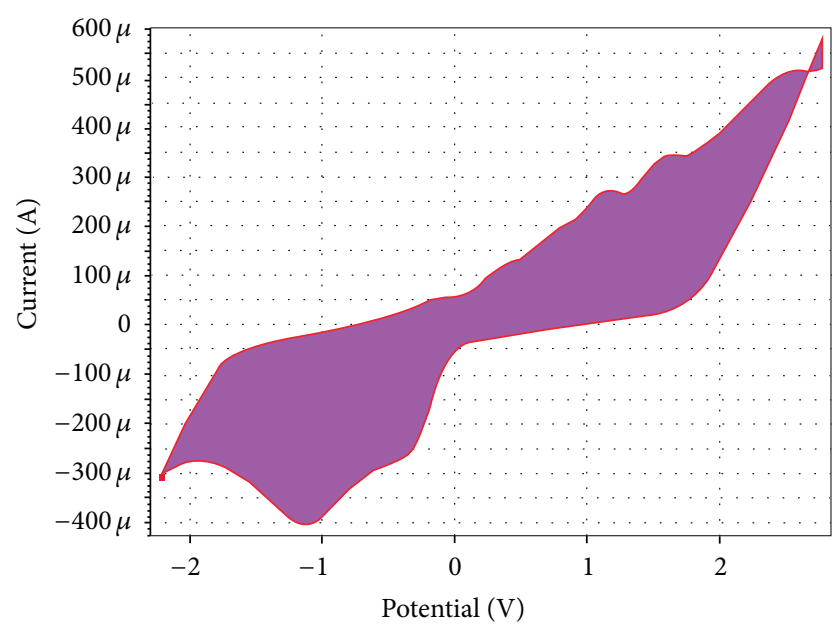

(a)

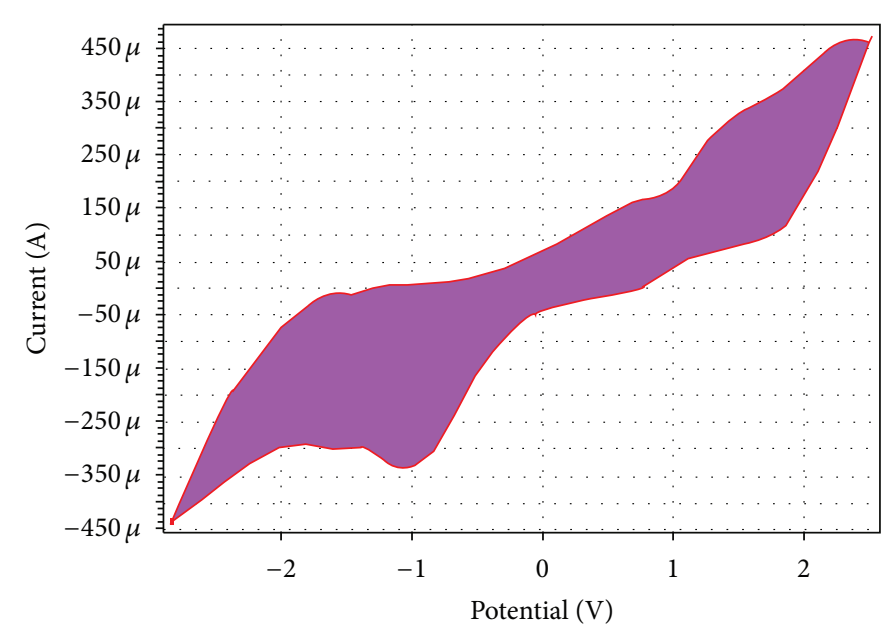

(b)

FIGURE 12: Cyclic voltammograms of the glassy carbon electrode in solutions containing $\left[\mathrm{CuCl}_{2}(\mathrm{DP})_{4}\right]$ in the (a) absence and (b) presence of CT-DNA. $V=0.1 \mathrm{Vs}^{-1}$ (versus $\mathrm{Ag} \mid \mathrm{Ag}^{+}$electrode).

values to $E_{1 / 2}=0.311 \mathrm{~V}$ and $\Delta E_{p}=-0.727 \mathrm{~V}$, respectively (Figure 12(b)). The ratio of $I_{\mathrm{pa}} / I_{\mathrm{pc}}$ was also found to be decreased further on addition of CT-DNA to the complex. The observed shift in the potentials and the decrease in ratio of peak currents suggest that the binding of $\mathrm{Ni}(\mathrm{II})$ complex to $C T$-DNA was weaker in nature. Also, the $\mathrm{KNi}(\mathrm{I}) / \mathrm{KNi}(\mathrm{II})$ value of 0.55 suggests that a stronger binding affinity exists for the $\mathrm{Ni}(\mathrm{II})$ state compared to the $\mathrm{Ni}(\mathrm{I})$ state in the nickel(II) complex.

Cyclic voltammogram of $\mathrm{Cu}(\mathrm{II})$ complex in the absence and presence of CT-DNA was shown in Figures 12(a) and 12(b). In the absence of $C T$-DNA, the cyclic voltammogram featured two anodic peaks $E_{\mathrm{pa}}(0.368$ and $-0.320 \mathrm{~V})$ and two cathodic peaks $E_{\mathrm{pc}}(0.113$ and $-0.765 \mathrm{~V})$ at $50 \mathrm{~m} \mathrm{Vs}^{-1}$. The first reduction and oxidation potential observed at
$E_{\mathrm{pc}}=0.113 \mathrm{~V}$ and $E_{\mathrm{pa}}=0.368 \mathrm{~V}$ was assigned to the redox couple $\mathrm{Cu}(\mathrm{III}) / \mathrm{Cu}(\mathrm{II})$. The second reduction and oxidation potential observed at $E_{\mathrm{pc}}=-0.765 \mathrm{~V}$ and $E_{\mathrm{pa}}=-0.320 \mathrm{~V}$ was attributed to the redox couple $\mathrm{Cu}(\mathrm{II}) / \mathrm{Cu}$ (I) (Table 10). The ratio of $I_{\mathrm{pa}} / I_{\mathrm{pc}}$ was less than unity for the above two redox couples. This also indicates that two quasireversible one-electron transfer reduction processes were involved.

In the presence of CT-DNA, the cyclic voltammogram of the copper(II) complex exhibited shifts in the anodic and cathodic peak potentials in association with decrease in peak currents, thereby indicating an existence of interaction between the copper(II) complex and CT-DNA. The drop in the voltammetric current can be attributed to the fast diffusion of the metal complex compared to the slowly diffusing DNA molecule. The $E_{1 / 2}$ values exhibit negative 
TABLE 10: Electrochemical behaviour of metal complexes in the absence and presence of CT-DNA.

\begin{tabular}{|c|c|c|c|c|c|c|c|c|c|c|}
\hline \multirow{2}{*}{ Complex } & \multirow{2}{*}{ Redox couple } & \multicolumn{2}{|c|}{$E_{\mathrm{pc}}(\mathrm{V})$} & \multicolumn{2}{|c|}{$E_{\mathrm{pa}}(\mathrm{V})$} & \multicolumn{2}{|c|}{$\Delta E_{p}(\mathrm{~V})$} & \multicolumn{2}{|c|}{$E_{1 / 2}(\mathrm{~V})$} & \multirow{2}{*}{$K_{R} / K_{O}$} \\
\hline & & Free & Bound & Free & Bound & Free & Bound & Free & Bound & \\
\hline$\left[\mathrm{NiCl}_{2}(\mathrm{DP})_{4}\right]$ & $\mathrm{Ni}(\mathrm{II}) / \mathrm{Ni}(\mathrm{I})$ & -0.267 & -0.182 & -0.858 & -0.571 & -0.491 & -0.389 & 0.309 & 0.311 & 0.55 \\
\hline \multirow{2}{*}[\mathrm{CuCl}_{2}(\mathrm{DP})_{4}]{} & $\mathrm{Cu}(\mathrm{III}) / \mathrm{Cu}(\mathrm{II})$ & 0.643 & 0.478 & 0.868 & 0.215 & 0.455 & 0.263 & 0.240 & 0.216 & 0.25 \\
\hline & $\mathrm{Cu}(\mathrm{II}) / \mathrm{Cu}(\mathrm{I})$ & -0.865 & -0.728 & -0.620 & -0.450 & 0.415 & 0.323 & -0.543 & -0.516 & 4.22 \\
\hline
\end{tabular}

$E_{1 / 2}=1 / 2\left(E_{\mathrm{pa}}+E_{\mathrm{pc}}\right), \Delta E_{\mathrm{p}}=E_{\mathrm{pa}}-E_{\mathrm{pc}}$, where $E_{\mathrm{pa}}$ and $E_{\mathrm{pc}}$ are anodic and cathodic peak potentials, respectively. Scan rate: $50 \mathrm{~m} \mathrm{Vs}{ }^{-1} \cdot I_{\mathrm{pc}}$ and $I_{\mathrm{pa}}$ are cathodic and anodic peak currents, respectively.

shifts of 0.216 and $-0.516 \mathrm{~V}$. The shift in the value of the formal potential $\left(\Delta E_{0}^{\prime}\right)$ can be used to estimate the ratio of equilibrium binding constants $\left(K_{R} / K_{O}\right)$ according to the model of interaction as described by Carter et al. [31], where $K_{R}$ and $K_{O}$ are the corresponding binding constants for the binding of reduced and oxidized species to DNA, respectively. The general progress can be described by a square scheme as shown in Scheme 1 similar to that proposed by Carter et al. [31]. The ratio of the equilibrium constants for binding of $\mathrm{Cu}(\mathrm{II})$ and $\mathrm{Cu}(\mathrm{I})$ species to the DNA has been estimated from the net shift in $E_{1 / 2}$ using the following equation:

$$
E_{b}^{O}-E_{f}^{O}=0.059 \log \left(\frac{K_{+}}{K_{2+}}\right)
$$

where $E_{b}^{O}$ and $E_{f}^{O}$ are the formal potentials of the $\mathrm{Cu}(\mathrm{II}) / \mathrm{Cu}(\mathrm{I})$ couple in the free and bound forms and $K_{+}$and $K_{2+}$ are the corresponding binding constants for the binding of +1 and +2 species to DNA, respectively, in each case. The $K_{\mathrm{Cu}(\mathrm{II})} / K_{\mathrm{Cu}(\mathrm{III})}$ and $K_{\mathrm{Cu}(\mathrm{II})} / K_{\mathrm{Cu} \text { (II) }}$ values for the copper(II) complex were calculated to be 0.25 and 4.2 , respectively, suggesting a stronger binding affinity for the $\mathrm{Cu}$ (II) species compared to the $\mathrm{Cu}(\mathrm{I})$ species. The above results of metalDNA interaction by the cyclic voltammogram studies confirm that $\mathrm{Cu}(\mathrm{II})$ complex bound to DNA via intercalation as well as electrostatic binding mode, whereas $\mathrm{Ni}(\mathrm{II})$ complex was bound through electrostatic binding mode.

3.18. DNA Viscosity Measurements. The values of $\left(\eta / \eta^{0}\right)^{1 / 3}$ were plotted against $[\mathrm{DNA}] /[$ complex] concentration values, for the metal complexes (where $\eta$ and $\eta^{0}$ are the specific viscosities of DNA in the presence and absence of the complex, resp.). The viscosity of DNA decreases with and increase in concentration of the added complex. The observed decreased relative viscosity may be explained by a binding mode process, which produces bends or kinks in the DNA, thereby reducing its effective length and hence its viscosity.

The effects of all the compounds on the viscosity of $C T$ DNA were shown in Figure 13. The viscosity measurements clearly show that the $\mathrm{Cu}$ (II) complex can interact between adjacent DNA base pairs, causing an extension in the DNA helix and thus increasing the viscosity of DNA with an increasing concentration of the solution. On the basis of all the spectroscopic studies together with the viscosity measurements, we find that the $\mathrm{Cu}(\mathrm{II})$ complex can bind to CT-DNA via an intercalative mode and the rest of the complex can interact with the DNA only by electrostatic mode [32].

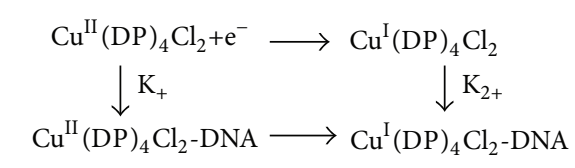

SCHEME 1

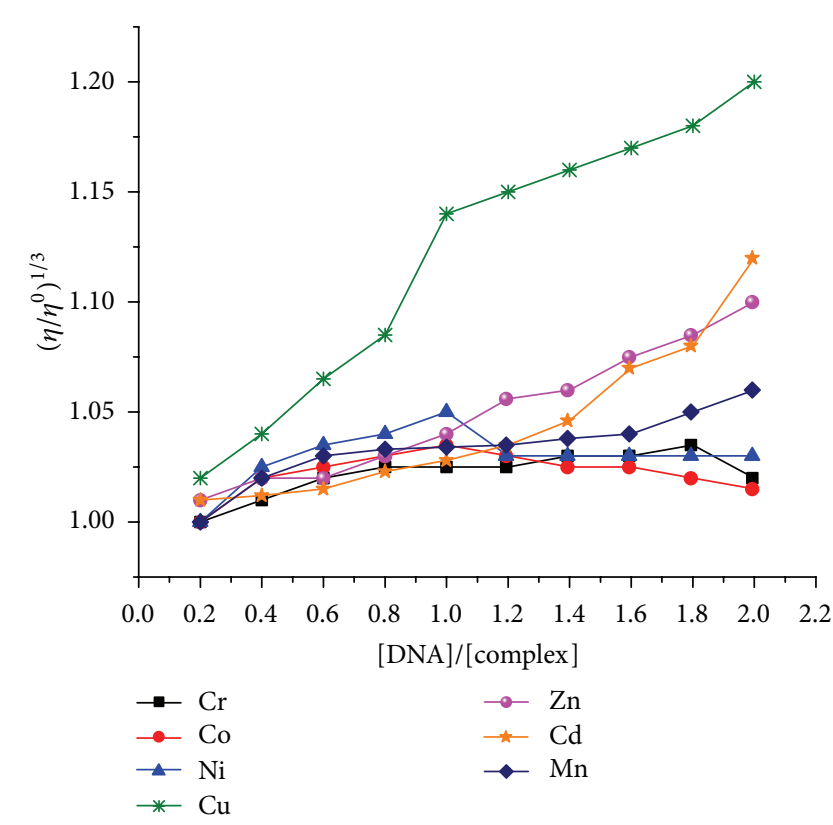

FIGURE 13: Viscosity titration values of CT-DNA with metal complexes.

\section{Conclusion}

The mixed ligand transition metal complexes of $4-\mathrm{N}, \mathrm{N}$ dimethylaminopyridine (DP) and chloride as primary and secondary ligands were synthesised, and the complexes were characterised by various physicochemical and spectroscopic tools. The ligand 4-N,N-dimethylaminopyridine has not appreciably interacted with the DNA, However, the synthesized metal(II) complexes showed a strong interaction with the DNA. Spectroscopic studies together with viscosity experiments and electrochemical method support that the complexes bind to $C T$-DNA by partial intercalation via its pyridine ring into the base pairs of the DNA. The binding constant shows that the DNA-binding affinity increases in the following order: $\mathrm{Cu}(\mathrm{II})>\mathrm{Ni}(\mathrm{II})>\mathrm{Co}(\mathrm{II})>\mathrm{Cd}(\mathrm{II})$. The complexes are having enhanced antibacterial and antifungal 
characters while compared to their parent dimethylaminopyridine ligand, and their biopotential property increases with the concentration. Thus, a few of these complexes could turn out to be a potential therapeutic material against pathogenic biotic agents.

\section{References}

[1] G. Kumar, R. Johari, and S. Devi, "Synthesis, physical characterization of $\mathrm{M}$ (III) transition metal complexes derived from thiodihydrazide and 5-tert-butyl-2-hydroxy-3-(3-phenylpent3-yl) benzaldehyde," E-Journal of Chemistry, vol. 9, no. 4, pp. 2119-2127, 2012.

[2] P. M. Secondo, J. M. Land, R. G. Baughman, and H. L. Collier, "Polymeric octahedral and monomeric tetrahedral group 12 pseudohalogeno $\left(\mathrm{NCX}^{-}: \mathrm{X}=\mathrm{O}, \mathrm{S}, \mathrm{Se}\right)$ complexes of $4-(N, N-$ dimethylamino)pyridine," Inorganica Chimica Acta, vol. 309, no. 1-2, pp. 13-22, 2000.

[3] K. Kalyanasundaram and M. Gratzel, "Applications of functionalized transition metal complexes in photonic and optoelectronic devices," Coordination Chemistry Reviews, vol. 77, no. 1, pp. 347-414, 1998.

[4] A. G. Gilman, L. S. Goodman, and A. Gilman, The Pharmacological Basis of Therapeutics, Macmillan, New York, NY, USA, 1980.

[5] T. Rosu, S. Pasculescu, V. Lazar, C. Chifiriuc, and R. Cernat, "Copper(II) complexes with ligands derived from 4-amino-2,3dimethyl-1-phenyl-3-pyrazolin-5-one: synthesis and biological activity," Molecules, vol. 11, no. 11, pp. 904-914, 2006.

[6] J. R. J. Sorensen, Metal Ions in Biological Systems, vol. 14, Marcel Dekker, New York, NY, USA, 1982.

[7] M. Melnik and A. Sirota, Challenges for Coordination Chemistry in the New Century, Slovak Technical University Press, Bratislava, Slovakia, 2001.

[8] K. Sharma, R. Singh, N. Fahmi, and R. V. Singh, "Microwave assisted synthesis, characterization and biological evaluation of palladium and platinum complexes with azomethines," Spectrochimica Acta Part A, vol. 75, no. 1, pp. 422-427, 2010.

[9] K. Deepa, N. T. Madhu, and P. K. Radhakrishnan, "Cadmium(II) complexes of 1,2-Di(Imino-4'-Antipyrinyl)ethane," Synthesis and Reactivity in Inorganic, Metal-Organic, and NanoMetal Chemistry, vol. 35, no. 10, pp. 883-888, 2005.

[10] G. H. Jeffery, J. Bassett, J. Mendham, and R. C. Denney, Vogel'S Textbook of Quantitative Chemical AnalySiS, Longman, New York, NY, USA, 5th edition, 1998.

[11] A. Rai, S. K. Sengupta, and O. P. Pandey, "Lanthanum(III) and praseodymium(III) complexes with isatin thiosemicarbazones," Spectrochimica Acta, vol. 61, no. 11-12, pp. 2761-2765, 2005.

[12] K. Nakamoto, Infrared and Raman Spectra of Inorganic and Coordination Compounds, Wiley Interscience, New York, NY, USA, 1978.

[13] C. Tuc, I. A. Morkan, and S. Ozkar, "Synthesis and spectroscopic characterization of group 6 pentacarbonyl(4-substituted pyridine)metal(0) complexes," Transition Metal Chemistry, vol. 32, no. 6, pp. 727-731, 2007.

[14] H. Icbudak, H. Olmez, O. Z. Yesilel et al., "Syntheses, characterization and crystal structures of novel amine adducts of metal saccharinates, orotates and salicylates," Journal of Molecular Structure, vol. 657, no. 1-3, pp. 255-270, 2003.

[15] A. B. P. Lever, Inorganic Electronic Spectroscopy, Elsevier, Amsterdam, The Netherlands, 1968.
[16] S. Cunha, S. M. Oliveira, J. Ferrari et al., "Structural studies of 4aminoantipyrine derivatives," Journal of molecular struture, vol. 752, no. 1-3, pp. 32-39.

[17] R. K. Prakash and B. Agrawal, "Studies on the effect of various anions and diphenyl sulfoxide on the stereochemistry of lanthanide(III) coordination compounds of $4\left[\mathrm{~N}-\left(2^{\prime}\right.\right.$-hydroxy$1^{\prime}$-naphthalidene)amino] antipyrinesemicarbazone," Transition Metal Chemistry, vol. 30, pp. 696-705, 2005.

[18] R. M. Silverstein, F. X. Webster, and David Kiemle, Spectrometric Identification of Organic Compounds, Wiley, New Delhi, India, 2007.

[19] F. W. Wehrli, A. P. Marchand, and S. Wehrli, Interpretation of Carbon-13 NMR Spectra, Wiley, New York, NY, USA, 1988.

[20] B. J. Hathaway and D. E. Billing, "The electronic properties and stereochemistry of mono-nuclear complexes of the copper(II) ion," Coordination Chemistry Reviews, vol. 5, no. 2, pp. 143-207, 1970.

[21] M. Padmanabhan, S. M. Kumary, X. Huang, and J. Li, "Succinate bridged dimeric $\mathrm{Cu}(\mathrm{II})$ system containing sandwiched noncoordinating succinate dianion: crystal structure, spectroscopic and thermal studies of $\left[(\text { phen })_{2} \mathrm{Cu}(\mu-\mathrm{L}) \mathrm{Cu}(\text { phen })_{2}\right] \mathrm{L} \cdot 12.5 \mathrm{H}_{2} \mathrm{O}$ $\left(\mathrm{H}_{2} \mathrm{~L}=\right.$ succinic acid; phen $=1,10$-phenanthroline $)$," Inorganica Chimica Acta, vol. 358, no. 13, pp. 3537-3544, 2005.

[22] J. Zsakó, G. Pokol, Cs. Novák, Cs. Várhelyi, A. Dobó, and G. Liptay, "Kinetic analyis of TG Data V. Spectroscopic and thermal studies of some cobalt(III) chelates with ethylenediamine," Journal of Thermal Analysis and Calorimetry, vol. 64, no. 2, pp. 843-856, 2001.

[23] P. Naumov, V. Jordonavska, O. Grupce, G. Jovanovski, and O. Grupc, "Thermal behaviour of the n-donor adducts of metal saccharinates: I. 2,2' -bipyridine saccharinato complexes of $\mathrm{Co}(\mathrm{II}), \mathrm{Ni}(\mathrm{II}), \mathrm{Cu}(\mathrm{II}), \mathrm{Zn}(\mathrm{II})$ and $\mathrm{Pb}(\mathrm{II})$," Journal of Thermal Analysis and Calorimetry, no. 1, pp. 59-67, 2001.

[24] G. S. Singh and T. Pheko, "Spectroscopic characterization of the 1-substituted 3,3-diphenyl-4-(2'-hydroxyphenyl)azetidin2-ones: Application of ${ }^{13} \mathrm{C} \mathrm{NMR},{ }^{1} \mathrm{H}^{-13} \mathrm{C}$ COSY NMR and mass spectroscopy," Spectrochimica Acta Part A, vol. 70, pp. 595-600, 2008.

[25] G. Turhan-Zitouni, M. Sivaci, F. S. Kilic, and K. Erol, "European journal of medicinal chemistry synthesis of some triazolylantipyrine derivatives and investigation of analgesic activity," European Journal of Medicinal Chemistry, vol. 36, no. 7-8, pp. 685-689, 2001.

[26] E. Drouhet, B. Dupont, L. Improvisi, M. A. Vivani, and A. M. Tortorando, In Vitro and in Vivo Evaluation of Antifungal Agents, Elsevier, Amsterdam, The Netherland, 1986.

[27] M. E. Reichmann, S. A. Rice, C. A. Thomas, and P. Doty, "A further examination of the molecular weight and size of desoxypentose nucleic acid," Journal of the American Chemical Society, vol. 76, no. 11, pp. 3047-3053, 1954.

[28] M. S. S. Babu, T. B. Patrudu, and K. H. Reddy, "DNA binding and cleavage activity of binuclear metal complexes with benzil$\alpha$-monoxime thiosemicarbzone," E-Journal of Chemistry, vol. 8, no. 1, pp. S309-S317, 2011.

[29] P. S. Mane, S. M. Salunke, and B. S. More, "Synthesis and structural studies of transition metal complexes with bidentate schiff base derived from 3-acetyl-6-methyl-(2H)-pyran-2,4(3)dione," E-Journal of Chemistry, vol. 8, no. 1, pp. S245-S252, 2011.

[30] A. Wolfe, G. H. Shimer Jr., and T. Meehan, "Polycyclic aromatic hydrocarbons physically intercalate into duplex regions of denatured DNA," Biochemistry, vol. 26, no. 20, pp. 6392-6396, 1987. 
[31] M. T. Carter, A. J. Bard, and J. Am, "Voltammetric studies of the interaction of tris(1,10-phenanthroline)cobalt(III) with DNA," journal of the American Chemical Society, vol. 109, no. 24, pp. 7528-7530, 1987.

[32] A. Raja, V. Rajendiran, P. U. Maheswari et al., "Copper(II) complexes of tridentate pyridylmethylethylenediamines: role of ligand steric hindrance on DNA binding and cleavage," Journal of Inorganic Biochemistry, vol. 99, no. 8, pp. 1717-1732, 2005. 

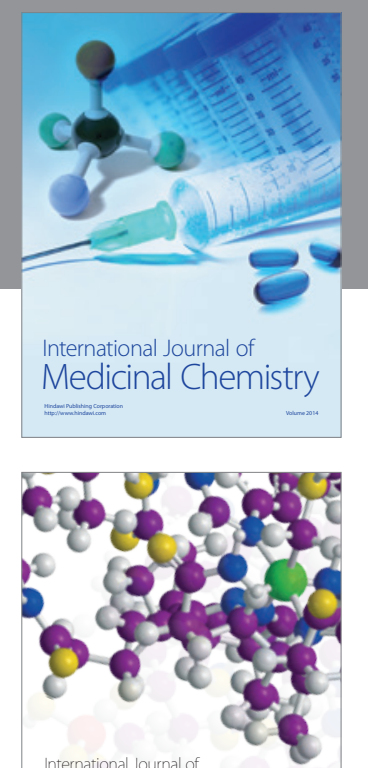

\section{Carbohydrate} Chemistry

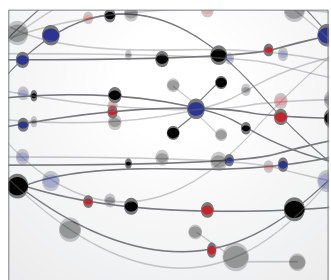

The Scientific World Journal
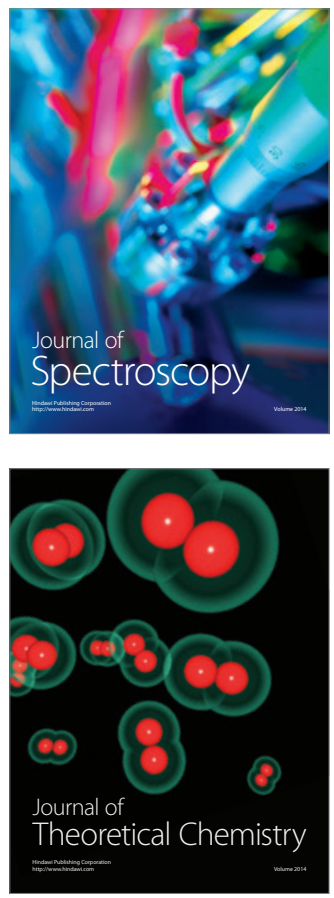
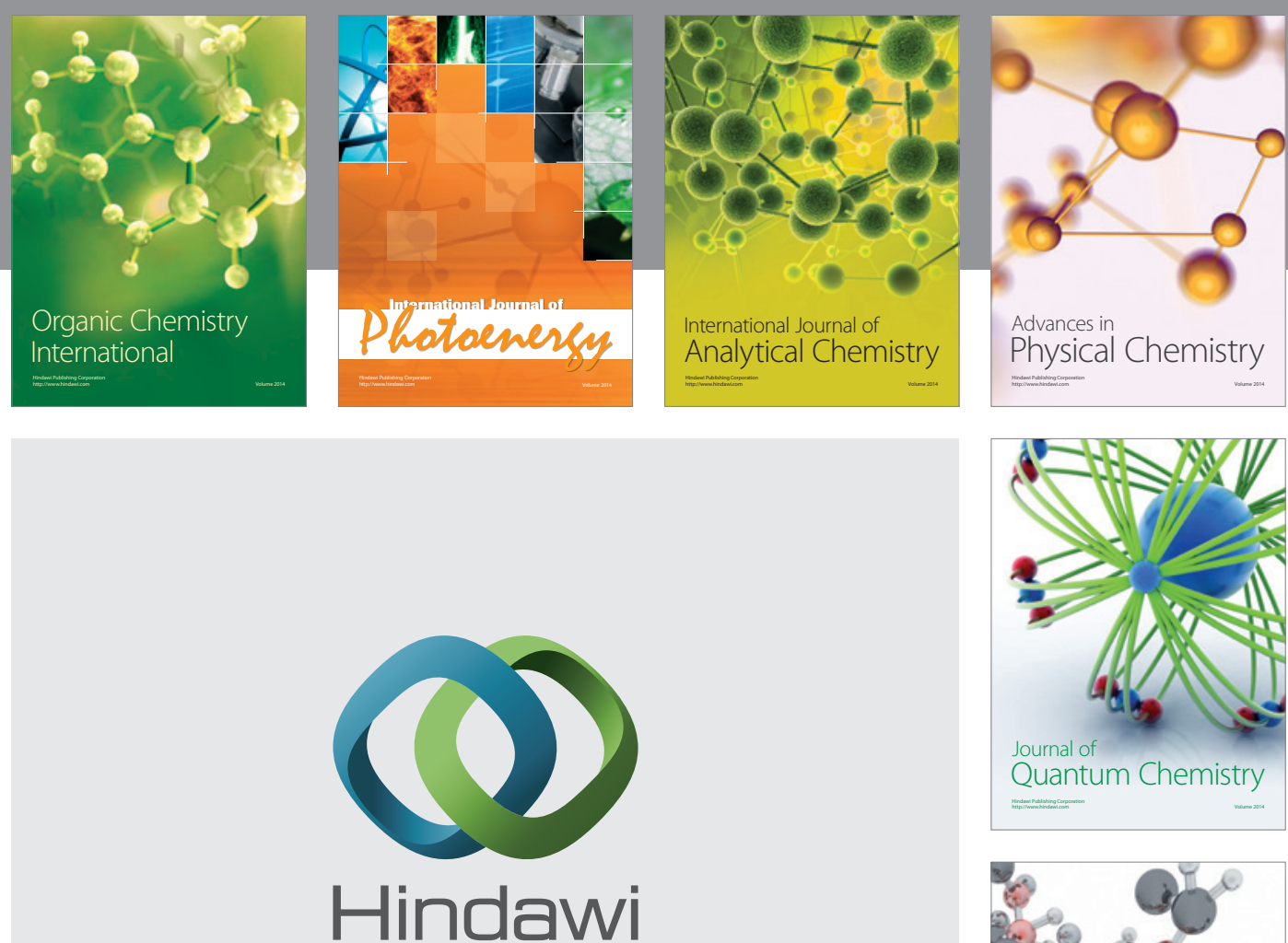

Submit your manuscripts at

http://www.hindawi.com

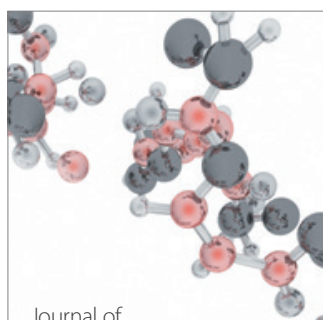

Analytical Methods

in Chemistry

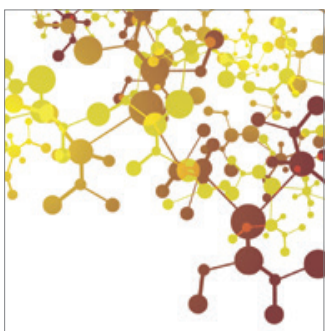

Journal of

Applied Chemistry

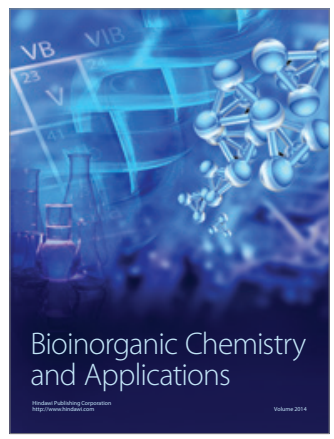

Inorganic Chemistry
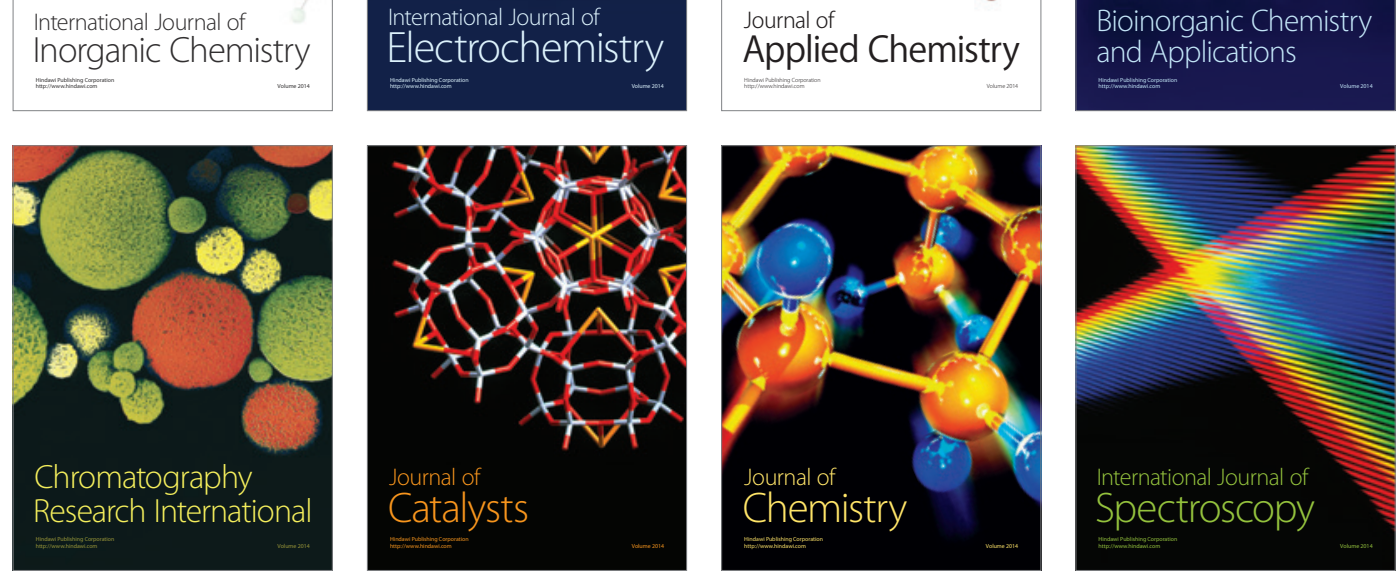